\title{
Ocean acidification impacts growth and shell mineralization in juvenile abalone (Haliotis tuberculata)
}

\author{
Auzoux-Bordenave Stéphanie ${ }^{1,8,{ }^{*}}$, Wessel Nathalie ${ }^{2}$, Badou Aïcha ${ }^{3}$, Martin Sophie ${ }^{4,8}$, \\ M'zoudi Saloua ${ }^{5}$, Avignon Solène ${ }^{1}$, Roussel Sabine ${ }^{6}$, Huchette Sylvain ${ }^{7}$, Dubois Philippe ${ }^{5}$
}

\author{
${ }^{1}$ Muséum National d'Histoire Naturelle, UMR "Biologie desOrganismes et Ecosystèmes Aquatiques" \\ (BOREA), MNHN/CNRS/SU/IRD, Station Marine de Concarneau, Concarneau, France \\ 2 Ifremer, Département Océanographie et Dynamique des Ecosystèmes (ODE), Nantes Cedex 3 , \\ France \\ ${ }^{3}$ Muséum National d'Histoire Naturelle, Station Marine de Concarneau, Concarneau, France \\ 4 UMR 7144 "Adaptation et Diversité en Milieu Marin" (AD2M), CNRS/SU, Station Biologique de \\ Roscoff, Roscoff Cedex, France \\ ${ }^{5}$ Université Libre de Bruxelles, Laboratoire de Biologie Marine, Brussels, Belgium \\ ${ }^{6}$ Université de Brest, CNRS, IRD, Ifremer, LEMAR, Plouzané, France \\ ${ }^{7}$ Ecloserie France Haliotis, Kerazan, Plouguerneau, France \\ 8 Sorbonne Université (SU), Paris, France
}

* Corresponding author : Stéphanie Auzoux-Bordenave, email address :

stephanie.auzoux-bordenave@mnhn.fr

\begin{abstract}
:
Ocean acidification $(\mathrm{OA})$ is a major global driver that leads to substantial changes in seawater carbonate chemistry, with potentially serious consequences for calcifying organisms. Marine shelled molluscs are ecologically and economically important species, providing essential ecosystem services and food sources for other species. Due to their physiological characteristics and their use of calcium carbonate (CaCO3) to build their shells, molluscs are among the most vulnerable invertebrates with regard to OA, with early developmental stages being particularly sensitive to $\mathrm{pH}$ changes. This study investigated the effects of CO2-induced OA on juveniles of the European abalone Haliotis tuberculata, a commercially important gastropod species. Six-month-old juvenile abalones were cultured for 3 months at four pH levels $(8.1,7.8,7.7,7.6)$ representing current and predicted near-future conditions. Survival, growth, shell microstructure, thickness, and strength were compared across the four $\mathrm{pH}$ treatments. After 3 months of exposure, significant reductions in juvenile shell length, weight, and strength were revealed in the $\mathrm{pH} 7.6$ treatment. Scanning electron microscopy observations also revealed modified texture and porosity of the shell mineral layers as well as alterations of the periostracum at $\mathrm{pH} 7.6$ which was the only treatment with an aragonite saturation state below 1 . It is concluded that low pH induces both general effects on growth mechanisms and corrosion of deposited shell in $\mathrm{H}$. tuberculata. This will impact both the ecological role of this species and the costs of its aquaculture.
\end{abstract}




\section{Introduction}

Anthropogenic carbon dioxide emission and its subsequent absorption by the ocean is responsible for seawater $\mathrm{pH}$ decrease and reduced availability of carbonate ions, leading to a decrease of calcium carbonate saturation state, two processes known as ocean acidification (OA) (Doney et al. 2009; Gattuso et al. 2015; IPPC 2014). Future projections suggest that there will be a $\mathrm{pH}$ reduction of 0.3 units by the year 2100 , threatening marine organisms that produce calcium carbonate exoskeletons and shells, such as corals, molluscs, and echinoderms (Kroeker et al. 2010; Hendricks et al. 2010; Hofmann et al. 2010; Widdicombe and Spicer 2008; Wittmann and Pörtner 2013). Because they do not compensate for acid-base disturbances, molluscs are considered to be among the most vulnerable invertebrates with respect to OA, with a pronounced sensitivity in larval and juvenile stages (Beniash et al. 2010; Gazeau et al. 2013; Melzner et al. 2009; Orr et al. 2005; Przeslawski et al. 2015, Ross et al. 2011). In marine shelled molluscs, OA has been shown to reduce larval survival, lengthen development time, alter morphology, and/or impair shell formation and calcification (Byrne et al. 2011; Duquette et al. 2017; Ellis et al. 2009; Fitzer et al. 2014a; Gazeau et al. 2010; Kurihara 2008; Noisette et al. 2014). Since many mollusc species are sources of commercially 
important foods, negative impacts of OA may also result in significant economic loss (Ekstrom et al. 2015; Gazeau et al. 2007).

Abalones are ecologically and economically important shelled gastropods, which are grazers in the marine ecosystem and a food delicacy for humans (Cook 2014; Huchette and Clavier 2004). Many abalone species worldwide have experienced severe population decline due to both overfishing and environmental perturbations, such as global warming and disease (Nicolas et al. 2002; Travers et al. 2009). In the context of the growth of worldwide aquaculture (Cook 2014), understanding the effects of stress on abalone physiology would allow the farmers to adapt their practices to minimize stress, prevent mortalities, and produce higher quality shellfish (Morash and Alter 2015).

The abalone Haliotis tubercula is a commercially important species, for which rearing over the whole life cycle is controlled in aquaculture (Courtois de Viçose et al. 2007). It displays a pelago-benthic life cycle with a larval planktonic stage followed by a critical metamorphosis into the benthic juvenile, making this species highly sensitive to environmental changes (Byrne et al. 2011). Several studies have focused on early life-history stages of abalone, especially on larvae, and have demonstrated adverse effects of elevated $\mathrm{CO}_{2}$, such as reduced survival, developmental delay, body and shell abnormalities, and reduction in mineralization (Byrne et al. 2011; Crim et al. 2011; Guo et al. 2015; Kimura et al. 2011; Onitsuka et al. 2018; Wessel et al. 2018; Zippay and Hofmann 2010). Shell formation has been extensively studied in $H$. tuberculata, revealing that aragonite is the main $\mathrm{CaCO}_{3}$ polymorph (Auzoux-Bordenave et al. 2010, 2015). Since aragonite is a less stable polymorph than calcite and is likely to be more susceptible to dissolution (Morse et al. 2007), the abalone shell is expected to be more sensitive to OA (Gazeau et al. 2013). The juvenile stage is a relevant model to study the effects of OA, since (1) it corresponds to the growing stage between larvae and adults and (2) it is a critical period where abalone are submitted to strong predation (Shepherd 1973). So far, only two studies investigated the responses of juvenile abalone to decreased seawater $\mathrm{pH}$. In juvenile Haliotis iris from New Zealand, a significant reduction of shell growth was observed under lower $\mathrm{pH}(0.3-0.5 \mathrm{pH}$ units less than the control), but no effect on respiration rate (Cunningham et al. 2016). More recently, the effects of low $\mathrm{pH}(-0.3$ to -0.5 units below control $\mathrm{pH})$ on juvenile $H$. discus hannai resulted in eroded shell surfaces, reduced growth rates, and altered 
biochemical composition and energy metabolism ( $\mathrm{Li}$ et al. 2018). The impact on shell microstructure or resistance to fracture was not investigated.

The goal of the present study was to investigate the effects of $\mathrm{CO}_{2}$-induced OA on survival, growth and shell mineralization and mechanics of juveniles of the European abalone $H$. tuberculata. Six-month-old juvenile abalones were cultured for 3 months under current and near-future $\mathrm{pH}$ conditions (8.1, 7.8, 7.7, and 7.6). Biological responses such as survival rate, growth performance (shell length, weight, and shell growth), and shell biomineralization were compared across the different $\mathrm{pH}$ treatments. SEM microscopy and fracture force analyses were performed to assess whether reduced $\mathrm{pH}$ has an influence on shell microstructure, thickness, and resistance.

\section{Materials and methods}

\section{Abalone collection and rearing}

Farmed, 6-month-old juvenile abalones $H$. tuberculata ( $n=540$ in total, $6.0 \pm$ $0.5 \mathrm{~mm}$ total shell length) were collected from nursery tanks at the France Haliotis abalone farm ( $48^{\circ} 36^{\prime} 46 \mathrm{~N}, 4^{\circ} 33^{\prime} 30 \mathrm{~W}$; Plouguerneau, France) in January 2013 and transported to the laboratory at the marine station,

Concarneau (MNHN, France). The abalone were randomly distributed into 12 experimental aquaria $(12 \mathrm{~L})$ supplied with filtered $3 \mu \mathrm{m}$ natural seawater renewed at a rate of $6 \mathrm{~L} \mathrm{~h}^{-1}$ and aerated with ambient air. Temperature was the local value in January, i.e., $9.3{ }^{\circ} \mathrm{C} \pm 0.5{ }^{\circ} \mathrm{C}$. Animals were conditioned in the laboratory, at ambient $p \mathrm{CO}_{2}$, at a density of 45 abalones per aquarium, for 3 weeks. Juvenile abalone shells usually have a green coloration, resulting from their grazing on Ulvella sp. algae at the farm. At the start of the experiment, the abalone diet was changed from green algae Ulvella to red Palmaria palmata which is a high-quality alga giving the best growth performance for H. tuberculata (Mercer et al. 1993). This changeover is part of standard procedure in aquaculture when juveniles reach 6-10 $\mathrm{mm}$ and results in a change of shell colouration from greenish to red (Marchais et al. 2017). Shell marking by algal feeding can be used as a proxy to determine growth in long-term stock enhancement program (Gallardo et al. 2003). This transition allowed us to mark the start (T0) of the experimental period for the evaluation of shell growth. The abalones were fed once a week ad libitum with the red macroalgae P. palmata. 


\section{Experimental design}

Experiments were carried out between March and June 2013 at the Concarneau marine station (France) according to an experimental design adapted from Martin et al. (2011). Juvenile abalones were exposed to four $\mathrm{pH}$ levels (total scale) for 3 months. The treatments consisted of a control at present-day $\mathrm{pH}, \mathrm{pH}_{\mathrm{T}} 8.1\left(\mathrm{CCO}_{2} \approx 400 \mu \mathrm{atm}\right)$, and three levels of predicted $\mathrm{pH}_{\mathrm{T}}$ according to different climate change scenarios, as outlined in Riebesell et al. (2010): 7.8 ( $\left.p \mathrm{CO}_{2} \approx 750 \mu \mathrm{atm}\right), 7.7\left(p \mathrm{CO}_{2} \approx 1000 \mu \mathrm{atm}\right)$, and $7.6\left(p \mathrm{CO}_{2}\right.$ $\approx 1400 \mu \mathrm{atm})$. Three replicate aquaria were set up per $\mathrm{pH}$ treatment.

\section{pH control and carbonate chemistry}

Low seawater $\mathrm{pH}_{\mathrm{T}}$ levels were obtained by bubbling $\mathrm{CO}_{2}$ (Air Liquide, France) into three $100 \mathrm{~L}$ header tanks supplied with filtered through-flowing seawater, continuously aerated with ambient air. Each header tank supplied three experimental $12 \mathrm{~L}$ aquaria at a rate of $6 \mathrm{~L} \mathrm{~h}^{-1}$. $p \mathrm{CO}_{2}$ in each tank was regulated through electro-valves controlled by a $\mathrm{pH}-$ stat system (IKS Aquastar, Germany). pH values of the IKS system were adjusted from daily measurements of the electromotive force (emf) in each aquarium using a $\mathrm{pH}$ meter (Metrohm $826 \mathrm{pH}$ mobile, Metrohm, Switzerland) with a glass electrode (Metrohm electrode plus), converted to total scale $\mathrm{pH}$ units $\left(\mathrm{pH}_{\mathrm{T}}\right)$ using Tris/ $\mathrm{HCl}$ and 2-aminopyridine/ $\mathrm{HCl}$ buffers (Dickson 2010). At the start of the experiment, $\mathrm{pH}$ was gradually decreased over 10 days by $0.05 \mathrm{pH}$ unit day ${ }^{-1}$ until the different target $\mathrm{pH}$ levels were reached.

Seawater parameters were monitored throughout the 3-month experiment. Temperature and $\mathrm{pH}_{\mathrm{T}}$ were recorded almost daily in each of the 12 experimental aquaria using a $\mathrm{pH}$ meter as described above. Salinity was measured twice a week using a conductivity meter (3110, WTW, Germany). Total seawater alkalinity $\left(A_{\mathrm{T}}\right)$ was measured every 2 weeks on $100 \mathrm{~mL}$ samples taken from each experimental aquarium. Seawater samples were filtered through $0.7 \mu \mathrm{m}$ Whatman GF/F membranes, immediately poisoned with mercury chloride, and stored in a cool dark place pending analyses. $A_{\mathrm{T}}$ was determined potentiometrically using an automatic titrator (TitroLine alpha, Schott SI Analytics, Germany), calibrated with the National Bureau of Standards scale. $A_{\mathrm{T}}$ was calculated using a Gran function applied to $\mathrm{pH}$ values ranging from 3.5 to 3.0, as described by Dickson et al. (2007), and corrected by comparison with standard reference material provided by Andrew G. Dickson (CRM Batch 111). Seawater carbonate chemistry, i.e., dissolved 
inorganic carbon (DIC), $p \mathrm{CO}_{2}$, and aragonite saturation state $\left(\Omega_{\text {aragonite }}\right)$, were calculated from $\mathrm{pH}_{\mathrm{T}}, A_{\mathrm{T}}$, temperature, and salinity with the $\mathrm{CO}_{2} \mathrm{SYS}$ program (Pierrot et al. 2006) using constants from Mehrbach et al. (1973) refitted by Dickson and Millero (1987).

\section{Juvenile survival and sampling}

Survival of the juvenile abalones was assessed almost daily during the 3 -month experiment. Any dead individuals were removed from the tanks immediately. Mortality was calculated as the proportion of the number of dead abalones vs the total number of abalones per tank and then averaged over the three replicates to calculate the mean survival for each $\mathrm{pH}$ treatment. Juvenile individuals were sampled at the start of the experiment (T0) and after 3 months of exposure (T3m). Soft tissues were dissected, while shells were rinsed with distilled water, dried, and stored at room temperature until analysis.

\section{Biometric measurements}

Shell length was measured with a Vernier calliper to the nearest $0.05 \mathrm{~mm}$ on 12 abalones from each replicate ( $n=36$ per $\mathrm{pH}$ treatment). Shell dry weight was measured on an analytical laboratory balance (Ohaus, Switzerland) to the nearest $0.001 \mathrm{mg}(n=21$ per $\mathrm{pH}$ treatment, except for $\mathrm{pH} 7.6, n=13)$. For shell weight, the lower number of individuals in $\mathrm{pH}_{\mathrm{T}} 7.6$ is due to the high percentage of broken shells in this condition; indeed, only the whole shells were used for shell weight determination and further SEM analysis on cross sections. The remaining shell samples were used for shell strength measurements. Shell index was calculated as the ratio total shell weight/(shell length $)^{3}(n=21$ per $\mathrm{pH}$ treatment, except for $\mathrm{pH} 7.6, n=13)$.

For the estimation of relative shell growth, the external mark on the shell induced by the change in algal diet (Fig. 1) was used as a proxy to estimate the shell area newly formed during the 3-month experiment. Shell surfaces were examined under a binocular microscope (Leica, Germany) and imaged with NIS elements software (Nikon, Japan). For the determination of relative shell growth, the newly formed area (red coloured) was measured by tracing its outline using Image J software. The ratio of red shell area/total shell area was calculated for each abalone shell and used as a proxy to determine relative shell growth $(n=36$ per $\mathrm{pH}$ treatment). All measurements were made by a single researcher, with the origin of each shell anonymized to eliminate 
subjective bias.

Fig. 1

Shell of a 9-month-old abalone showing the transition from greenish to red colouration induced by the change of algal diet (black arrow); the transition mark was used as a proxy to estimate the shell area newly (nsa) formed during the 3-month experiment

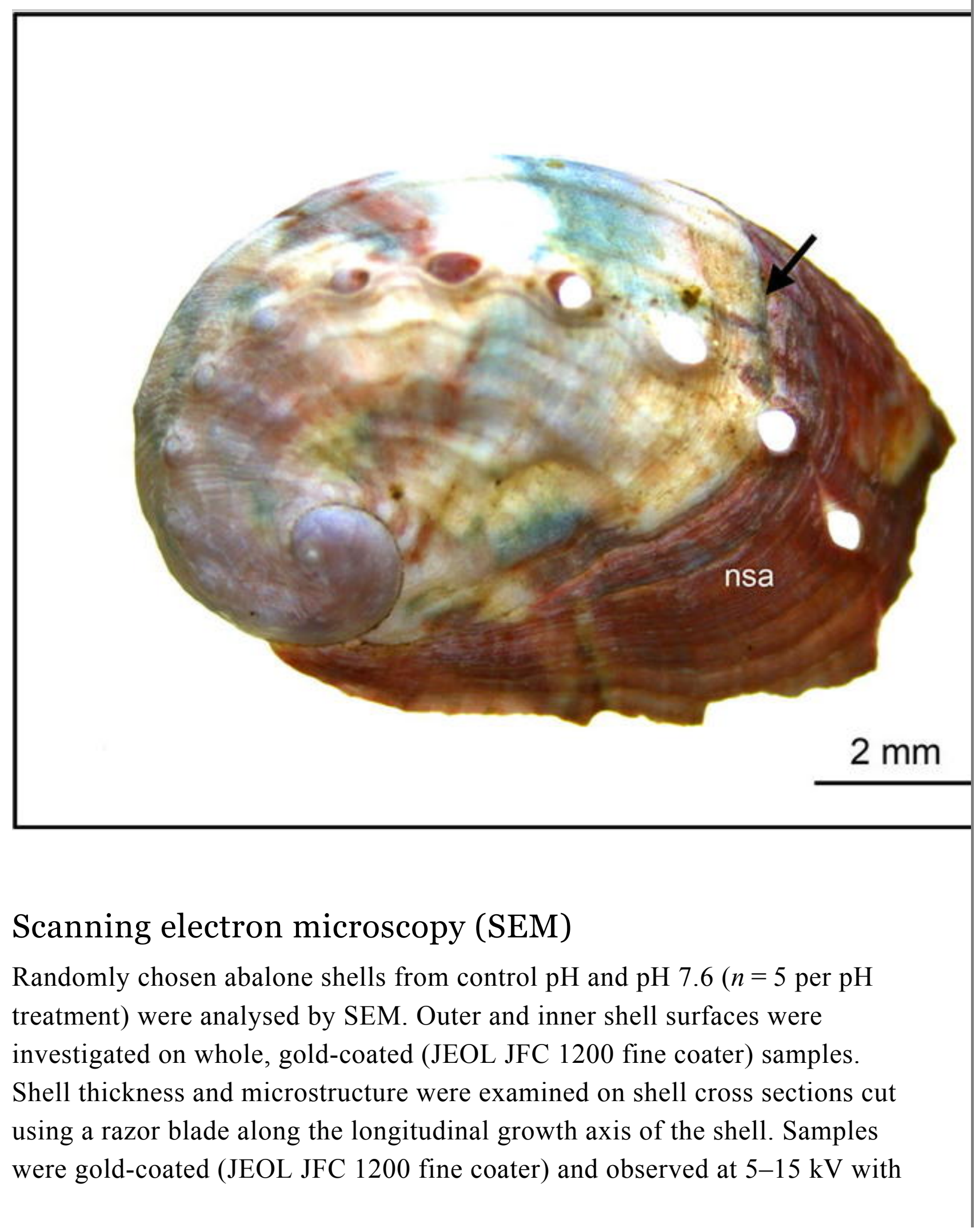


either a JEOL JSM-840A or a Sigma 300 FE-SEM scanning electron microscope (SEM, Plateau Technique de Microscopie Electronique, MNHN, Paris and Concarneau, France). Shell thickness (total, outer spherulitic, and nacre layer thickness) measurements were made on SEM images of the cross sections using Image J software from 6 to 9 transects per shell section (Fig. $\mathrm{S} 1$, electronic supplementary material).

\section{Biomechanical tests}

Shell strength (resistance) of abalone shells was measured individually ( $n=10$ shells/pH treatment) using a simple compression method. The shells were placed on a metal block with the opening downwards (i.e., in what would be their natural position on a rocky substrate) and the mechanical test was carried out using a second metal block fixed on the load frame of the force stand (Instron 5543), which was then lowered onto the shell at a speed of $0.3 \mathrm{~mm} \mathrm{~min} \mathrm{~m}^{-1}$ (simple compression test) until fracture. Displacement and force were recorded continuously at a frequency of $10 \mathrm{~Hz}$ using a $100 \mathrm{~N}$ force cell (Instron 2530-100 N). The failure force was recorded for each specimen. A representative curve of compressive force vs displacement is presented in supplementary Fig. S2. A stress-strain relationship was not established because of the absence of symmetry in the abalone shell and the difficulty to define the surface on which the force is applied.

\section{Statistical analysis}

All statistical analyses were performed with Rstudio software (R Core Team 2015). Differences in juvenile survival, shell length and weight, relative growth, and shell index across $\mathrm{pH}$ treatments were assessed using generalized linear model (GLM) ANOVAs after testing the normality of data, normality of residuals and homogeneity of variances ( $\mathrm{pH}$ : fixed factor, tank: random factor nested into $\mathrm{pH}$ ). In the few cases where data distribution deviated from normality and/or variances was not homogeneous, data were log-transformed to ensure compliance with ANOVA assumptions. If the homogeneity of variance was not verified, a Welch test was performed, as recommended by Day and Quinn (1989). Post hoc HSD Tukey tests, using the appropriate mean-square error, were used to test the differences between the group means. To detect any significant differences in shell thickness, unpaired Student's $t$ tests were performed. To assess the effect of decreased $\mathrm{pH}$ on shell strength, regression analyses were performed to look at the relationships between fracture force and shell weight. ANCOVA model was used to compare linear 
regression models and evaluate the effect of $\mathrm{pH}$, using weight as a covariate. All data are presented as mean $\pm \mathrm{SD}$, except where otherwise stated.

Differences were considered significant at $P<0.05$.

\section{Results}

\section{Seawater parameters}

Mean values of seawater carbonate chemistry parameters for the four $\mathrm{pH}$ treatments are given in Table 1. Seawater temperature followed the natural variations found in the bay of Concarneau, ranging from $9.3 \pm 0.5^{\circ} \mathrm{C}$ at the start of experiment (early March) to $16.1 \pm 0.5{ }^{\circ} \mathrm{C}$ at the end (mid-June), with the mean ranging from $12.1 \pm 1.8$ to $12.4 \pm 1.8^{\circ} \mathrm{C}$ according to treatment. The $\mathrm{pH}_{\mathrm{T}}$ of the experimental aquaria was maintained close to the nominal values throughout the experiment, at $\mathrm{pH}_{\mathrm{T}}=8.10\left(p \mathrm{CO}_{2}=347 \pm 5 \mu \mathrm{atm}\right), \mathrm{pH}_{\mathrm{T}}=7.81$ $\left(p \mathrm{CO}_{2}=746 \pm 10 \mu \mathrm{atm}\right), \mathrm{pH}_{\mathrm{T}}=7.73\left(p \mathrm{CO}_{2}=934 \pm 13 \mu \mathrm{atm}\right)$, and $\mathrm{pH}_{\mathrm{T}}=7.65$ $\left(p \mathrm{CO}_{2}=1157 \pm 35 \mu \mathrm{atm}\right)$. Mean total alkalinity $\left(A_{\mathrm{T}}\right)$ measured in the experimental aquaria ranged from $2305 \pm 28$ to $2312 \pm 30 \mu \mathrm{Eq} \mathrm{kg}^{-1}(n=8$ per $\mathrm{pH}$ treatment) over the course of the experiment and presented only slight differences between treatments. Salinity was $35.2 \pm 1.7$ in all experimental aquaria. $\Omega_{\text {calcite }}$ was always greater than 1 in all four $\mathrm{pH}$ treatments, while $\Omega_{\text {aragonite }}$ only reached values below 1 in the lowest $\mathrm{pH}_{\mathrm{T}}$ treatment (7.6).

\section{Table 1}

Parameters of seawater carbonate chemistry during the experiment (mean $\pm \mathrm{SD}$ )

\begin{tabular}{|c|c|c|c|c|c|c|}
\hline $\begin{array}{l}\text { Nominal } \\
\text { pH }\end{array}$ & $\mathbf{p H}_{\mathrm{T}}$ & $\begin{array}{l}\text { Temperature } \\
\left({ }^{\circ} \mathrm{C}\right)\end{array}$ & $\begin{array}{l}\text { TA } \\
\left(\mu \mathbf{E q ~ k g}{ }^{-1}\right)\end{array}$ & 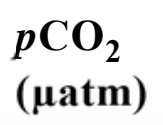 & $\begin{array}{l}\text { DIC } \\
\left(\mu \mathrm{mol} \mathrm{kg}{ }^{-1}\right)\end{array}$ & $\begin{array}{l}\mathrm{HCO}_{3}^{-} \\
\left(\mu \mathrm{mol} \mathrm{kg}{ }^{-1}\right)\end{array}$ \\
\hline 8.1 & $\begin{array}{l}8.11 \\
\pm \\
0.04\end{array}$ & $12.4 \pm 1.8$ & $2305 \pm 28$ & $\begin{array}{l}335 \pm \\
33\end{array}$ & $2070 \pm 22$ & $1890 \pm 35$ \\
\hline 7.8 & $\begin{array}{l}7.81 \\
\pm \\
0.05\end{array}$ & $12.1 \pm 1.7$ & $2312 \pm 30$ & $\begin{array}{l}750 \pm \\
18\end{array}$ & $2209 \pm 18$ & $2088 \pm 24$ \\
\hline 7.7 & $\begin{array}{l}7.71 \\
\pm \\
0.04\end{array}$ & $12.3 \pm 1.7$ & $2308 \pm 37$ & $\begin{array}{l}958 \pm \\
108\end{array}$ & $2237 \pm 17$ & $2124 \pm 20$ \\
\hline
\end{tabular}

$\mathrm{pH}$ on the total scale $\left(\mathrm{pH}_{\mathrm{T}}\right)$, temperature $\left({ }^{\circ} \mathrm{C}\right)$, salinity, and total alkalinity $\left(\mu \mathrm{Eq} \mathrm{kg}^{-1}\right)$ pressure $\left(p \mathrm{CO}_{2} ; \mu \mathrm{atm}\right)$, dissolved inorganic carbon (DIC; $\left.\mu \mathrm{mol} \mathrm{\textrm {kg } ^ { - 1 }}\right), \mathrm{HCO}_{3}^{-}, \mathrm{CO}_{3}{ }^{2-}$, ( $\left.\Omega_{\text {aragonite }}\right)$, and calcite saturation state $\left(\Omega_{\text {calcite }}\right)$ using the $\mathrm{CO}_{2} \mathrm{SYS}$ program. $\mathrm{pH}_{\mathrm{T}}$ and recorded almost daily throughout the experiment ( $n=76 \mathrm{per} \mathrm{pH}$ treatment). Salinity u $35.3 \pm 1.3, n=26$ ) and total alkalinity was measured every 2 weeks throughout the ex] 


\begin{tabular}{|c|c|c|c|c|c|c|}
\hline $\begin{array}{l}\text { Nominal } \\
\text { pH }\end{array}$ & $\mathrm{pH}_{\mathrm{T}}$ & $\begin{array}{l}\text { Temperature } \\
\left({ }^{\circ} \mathrm{C}\right)\end{array}$ & $\begin{array}{l}\text { TA } \\
\left(\mu \mathrm{Eq} \mathrm{kg}{ }^{-1}\right)\end{array}$ & $\begin{array}{l}p \mathrm{CO}_{2} \\
\text { ( } \mu \text { atm) }\end{array}$ & $\begin{array}{l}\text { DIC } \\
\left(\mu \mathrm{mol} \mathrm{kg}{ }^{-1}\right)\end{array}$ & $\begin{array}{l}\mathrm{HCO}_{3}^{-} \\
\left(\mu \mathrm{mol} \mathrm{kg}{ }^{-1}\right)\end{array}$ \\
\hline 7.6 & $\begin{array}{l}7.60 \\
\pm \\
0.05\end{array}$ & $12.1 \pm 1.8$ & $2309 \pm 34$ & $\begin{array}{l}1259 \\
\pm 140\end{array}$ & $2274 \pm 16$ & $2164 \pm 17$ \\
\hline
\end{tabular}

$\mathrm{pH}$ on the total scale $\left(\mathrm{pH}_{\mathrm{T}}\right)$, temperature $\left({ }^{\circ} \mathrm{C}\right)$, salinity, and total alkalinity $\left(\mu \mathrm{Eq} \mathrm{kg}^{-1}\right)$ pressure $\left(\mathrm{CO}_{2} ; \mu \mathrm{atm}\right)$, dissolved inorganic carbon (DIC; $\left.\mu \mathrm{mol} \mathrm{kg}^{-1}\right), \mathrm{HCO}_{3}{ }^{-}, \mathrm{CO}_{3}{ }^{2-}$, ( $\left.\Omega_{\text {aragonite }}\right)$, and calcite saturation state $\left(\Omega_{\text {calcite }}\right)$ using the $\mathrm{CO}_{2} \mathrm{SYS}$ program. $\mathrm{pH}_{\mathrm{T}}$ and recorded almost daily throughout the experiment $(n=76$ per $\mathrm{pH}$ treatment). Salinity $\mathrm{n}$ $35.3 \pm 1.3, n=26$ ) and total alkalinity was measured every 2 weeks throughout the ex]

\section{Survival}

The mortality of juvenile abalones was very low, with a survival percentage ranging between $90.9 \pm 10.3 \%$ and $96 \pm 3.3 \%$ at the end of the experiment. There were no significant differences in survival among the four $\mathrm{pH}$ treatments [ANOVA, $F(3,8)=0.367, P=0.78$ ].

\section{Shell growth}

Abalones grew in all treatments, from $6.0 \pm 0.5 \mathrm{~mm}$ at the start of the experiment to $8.3 \pm 1.0 \mathrm{~mm}\left(\mathrm{pH}_{\mathrm{T}} 8.1\right), 8.7 \pm 1.0 \mathrm{~mm}\left(\mathrm{pH}_{\mathrm{T}} 7.8\right), 8.1 \pm 1.0 \mathrm{~mm}$ $\left(\mathrm{pH}_{\mathrm{T}} 7.7\right)$, and $7.8 \pm 1.1 \mathrm{~mm}\left(\mathrm{pH}_{\mathrm{T}} 7.6\right)$ after 3 months. Total shell length after 3 months differed significantly according to $\mathrm{pH}$ treatment [ANOVA, $F(3,8)=$ 4.78, $P=0.034$, Fig. 2]: juveniles exposed to $\mathrm{pH}_{\mathrm{T}} 7.6$ were significantly smaller than those exposed to $\mathrm{pH}_{\mathrm{T}} 7.8$ (Post hoc Tukey, $t 8=-3.656, P=$ 0.027 , Table 2). No significant differences were observed between juveniles exposed to $\mathrm{pH}_{\mathrm{T}} 7.7,7.8$ and the control $\mathrm{pH}_{\mathrm{T}}(8.1)$.

Fig. 2

Shell length of juvenile abalones $H$. tuberculata exposed to decreased $\mathrm{pH}_{\mathrm{T}}$ values. Centre lines of box plots show the medians; box limits indicate the first and third quartiles, respectively, with whiskers encompassing data within 1.5 times the spread from the median $(n=36$ per $\mathrm{pH}$ treatment). Different letters indicate significant differences between $\mathrm{pH}$ treatments $(P<0.05)$ 


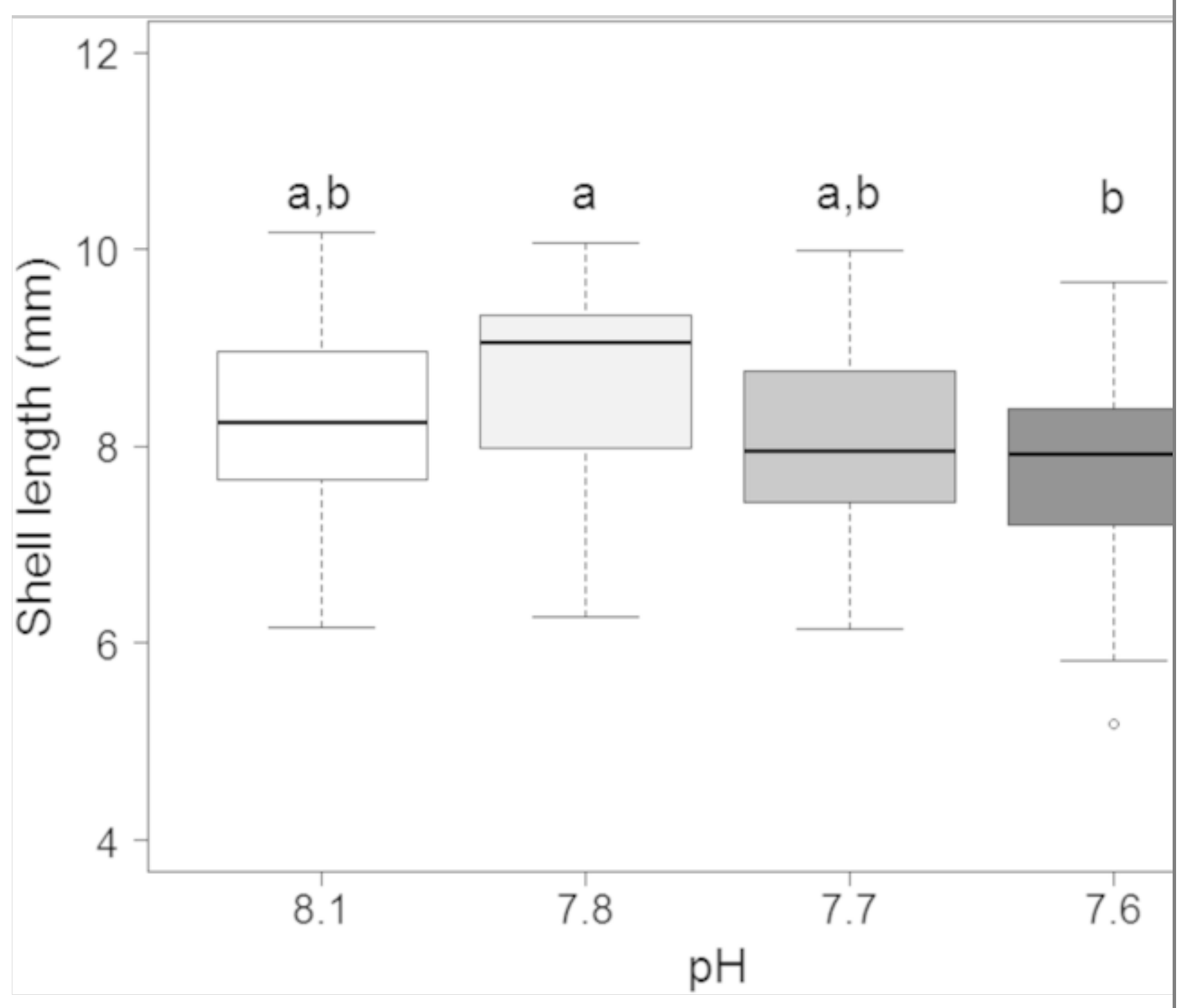

Table 2

Summary of statistics (A) nested ANOVA results of the effects of $\mathrm{pH}$ on shell length, weight, relative growth, and Welch test on shell density index in juvenile abalone $H$. tuberculata ( $\mathrm{pH}$ : fixed factor, tank: random factor nested into $\mathrm{pH}$ ), (B) multiple comparison Tukey's HSD test testing the influence of $\mathrm{pH}$ on shell length and weight and Welch test on shell density index in juvenile abalone $H$. tuberculata

\begin{tabular}{l|l|l|l} 
SS & $d f$ & MS & $F$ ratio
\end{tabular}

(A)

Shell length

$\mathrm{pH}$

14.66

3

4.89

4.78

$\mathbf{0 . 0 3 4}$

Significant $P$ values in bold $(P<0.05)$

${ }^{\text {a }}$ Log transformation

${ }^{\mathrm{b}}$ Welch test

${ }^{\mathrm{c} P a i r w i s e}$ comparisons using $t$ test (Welch) 


\begin{tabular}{|c|c|c|c|c|c|}
\hline & SS & $d f$ & MS & $F$ ratio & $P$ value \\
\hline Residuals & 8.18 & 8 & 1.02 & & \\
\hline Error (tank) & 131.6 & 129 & 1.02 & & \\
\hline \multicolumn{6}{|l|}{ Shell weight ${ }^{\mathrm{a}}$} \\
\hline $\mathrm{pH}$ & 1.28 & 3 & 0.42 & 24.43 & $<0.001$ \\
\hline Residuals & 0.14 & 8 & 0.02 & & \\
\hline Error (tank) & 1.41 & 67 & 0.02 & & \\
\hline
\end{tabular}

Relative shell growth

\begin{tabular}{|l|l|l|l|l|l|}
\hline $\mathrm{pH}$ & 0.034 & 3 & 0.11 & 0.626 & 0.618 \\
\hline Residuals & 0.147 & 8 & 0.02 & & \\
\hline Error (tank) & 0.752 & 126 & 0.006 & & \\
\hline
\end{tabular}

Shell density index ${ }^{b}$

\begin{tabular}{l|l|l|l|l|l|}
$\mathrm{pH}$ & - & 3 & - & 14.47 & $\mathbf{0 . 0 1 3}$
\end{tabular}

(B)

\begin{tabular}{|c|c|c|c|c|c|c|}
\hline $\mathrm{pH}$ groups & $7.6 / 7.7$ & $7.6 / 7.8$ & $7.6 / 8.1$ & $7.7 / 7.8$ & $7.7 / 8.1$ & $7.8 / 8.1$ \\
\hline Shell length & 0.736 & 0.027 & 0.305 & 0.119 & 0.838 & 0.347 \\
\hline Shell weight & $<0.005$ & $<0.001$ & $<0.001$ & 0.139 & 0.910 & 0.353 \\
\hline Shell density index ${ }^{\mathrm{c}}$ & $<\mathbf{0 . 0 0 2}$ & $<0.005$ & $<0.001$ & 1 & 1 & 1 \\
\hline
\end{tabular}

Significant $P$ values in bold $(P<0.05)$

${ }^{\text {a }}$ Log transformation

${ }^{\mathrm{b}}$ Welch test

${ }^{\mathrm{c}}$ Pairwise comparisons using $t$ test (Welch)

Shell weight was significantly affected by $\mathrm{pH}$ [ANOVA, $F(3,8)=24.43, P<$ 0.001, Fig. 3], being lower for juveniles exposed to $\mathrm{pH}_{\mathrm{T}} 7.6$ compared with those grown in other $\mathrm{pH}$ treatments (post hoc Tukey, $P<0.005$, Table 2). Relative shell growth, determined as the ratio of red shell area/total shell area, did not differ significantly between $\mathrm{pH}$ treatments [ANOVA, $F(3,8)=0.626$, $P=0.618$, Table 2].

\section{Fig. 3}

Shell weight of juvenile abalones $H$. tuberculata exposed to decreased $\mathrm{pH}_{\mathrm{T}}$ 
values. Centre lines of box plots show the medians; box limits indicate the first and third quartiles, respectively, with whiskers encompassing data within 1.5 times the spread from the median $(n=22$ per $\mathrm{pH}$ treatment, except for $\mathrm{pH} 7.6 n$ $=13$ ). Different letters indicate significant differences between $\mathrm{pH}$ treatments $(P<0.05)$

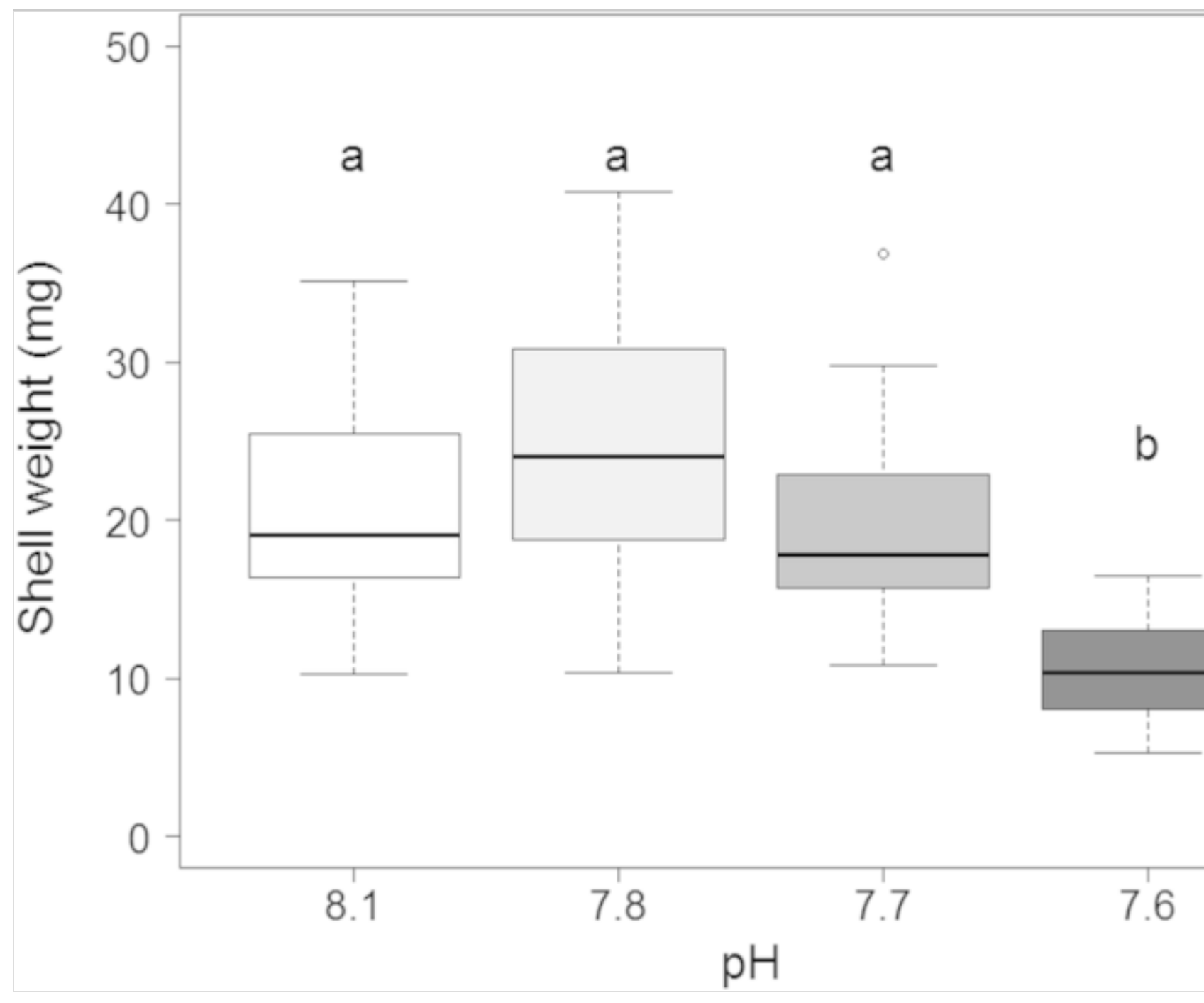

\section{Shell calcification}

Shell index was significantly affected by $\mathrm{pH}$ [Welch's $F$ test, $F(3,3.982)=$ 14.48, $P=0.013$; Fig. 4]. Abalones in the $\mathrm{pH}_{\mathrm{T}} 7.6$ treatment had a reduced shell index compared to those grown in the other $\mathrm{pH}$ treatments $(P<0.005$, Table 2).

\section{Fig. 4}

Shell index (determined as the ratio shell weight/shell length ${ }^{3}$ ) of juvenile abalones under different $\mathrm{pH}_{\mathrm{T}}$ conditions. Centre lines of box plots show the medians; box limits indicate the first and third quartiles, respectively, with 
whiskers encompassing data within 1.5 times the spread from the median $(n=$ 22 per $\mathrm{pH}$ treatment, except for $\left.\mathrm{pH}_{\mathrm{T}} 7.6 n=13\right)$. Different letters indicate significant differences between $\mathrm{pH}$ treatments $(P<0.05)$

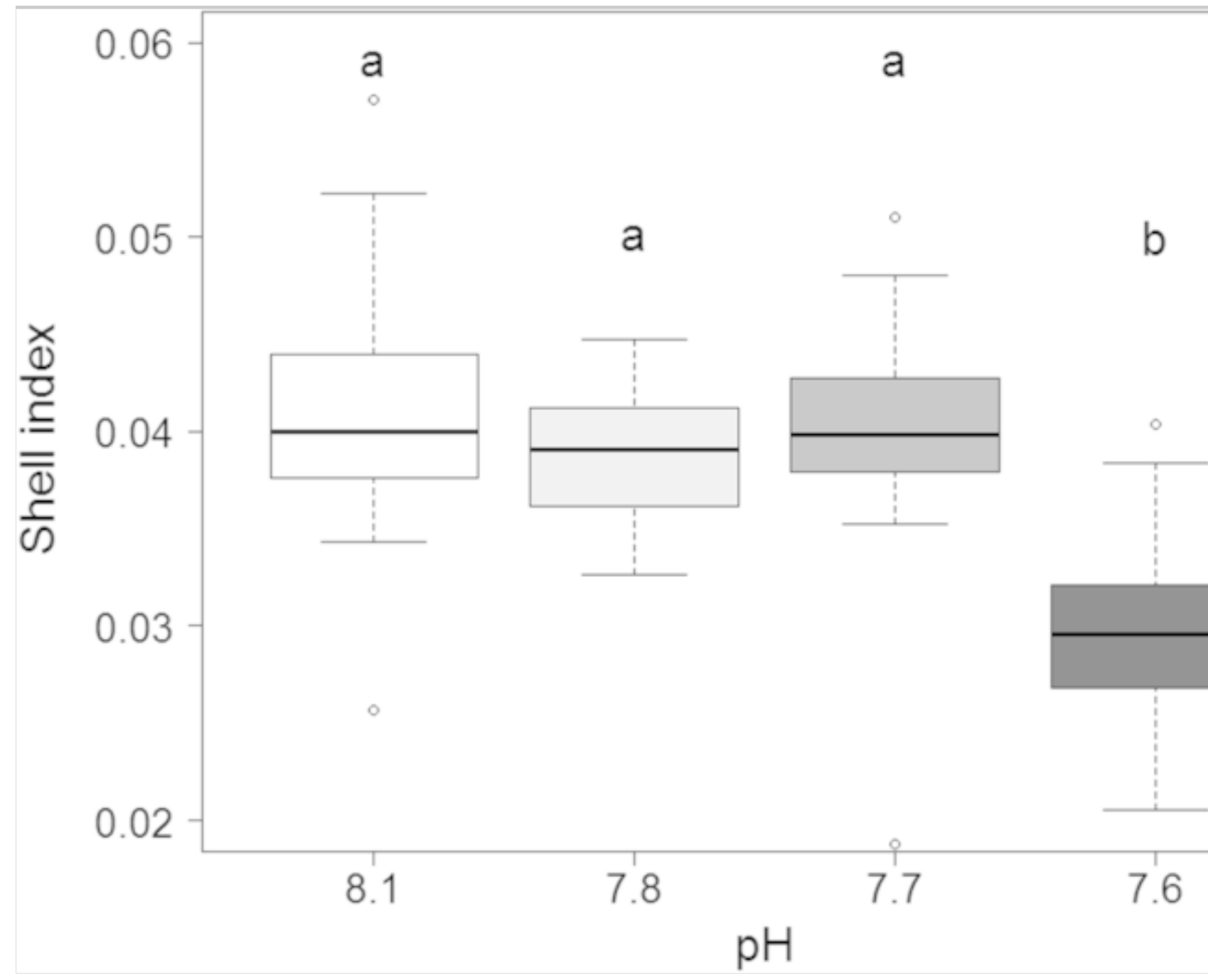

SEM examination of abalone shells grown at $\mathrm{pH}_{\mathrm{T}} 8.1$ and 7.6 revealed differences in the texture and porosity of both outer and inner surface layers. Under control conditions, almost intact periostracum were observed with typical ornamentations (ridge and groove pattern) and regular organic sheets (Fig. 5a, c). At lower $\mathrm{pH}$, the periostracum revealed bleached areas and a corroded surface with numerous small holes (Fig. 5b, d). In some individuals, large holes were observed between the apertures as a result of shell corrosion (Fig. 5b). The delamination of surface organic sheets revealed biominerals of the underlying spherulitic layer (Fig. 5d). In control shells, the inner nacreous layer had a homogeneous surface, with a gradual maturation of aragonite platelets (Fig. 6a, c, e). By contrast, juvenile shells from the low $\mathrm{pH}$ treatment (pH 7.6) were characterized by a partial degradation of the inner nacreous 
layer, resulting in decreased size of aragonite platelets and irregularities of their edges (Fig. 6b, d, f).

\section{Fig. 5}

SEM images of abalone outer shell surface in control conditions $\left(\mathrm{pH}_{\mathrm{T}} 8.1\right.$ : a, c) and under lower $\mathrm{pH}\left(\mathrm{pH}_{\mathrm{T}}\right.$ 7.6: b, d). a Periostracum in the control, showing a homogenous surface with the typical ridge and groove patterns; $\mathbf{b}$ periostracum in the $\mathrm{pH}_{\mathrm{T}} 7.6$ treatment, showing bleached areas and corroded surface; $\mathbf{c}$ detail of the shell area boxed in a, showing regular organic sheets; $\mathbf{d}$ Details of the shell area boxed in $\mathbf{b}$, showing the delamination of organic sheets and revealing biominerals of the underlying spherulitic layer
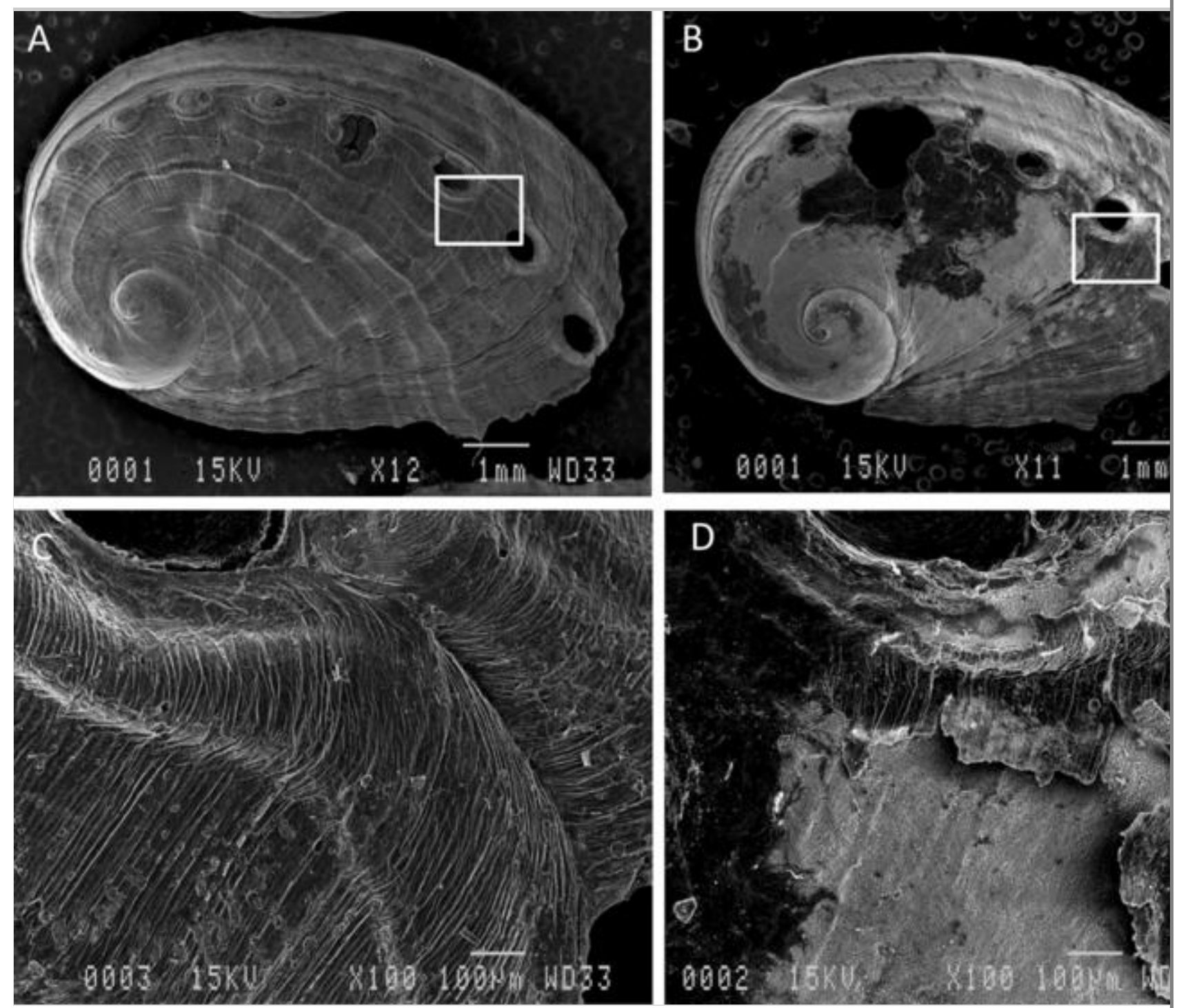

Fig. 6

SEM images of abalone inner nacreous surface in control conditions $\left(\mathrm{pH}_{\mathrm{T}}\right.$ 8.1: a, c, e) and under low $\mathrm{pH}_{\mathrm{T}} 7.6$ (b, d, f). a Inner nacreous layer of control shell; b inner nacreous layer of shell exposed to $\mathrm{pH}_{\mathrm{T}} 7.6$; $\mathbf{c}$ detail of the nacre growth 
region boxed in A showing gradual maturation of aragonite platelets; $\mathbf{d}$ detail of the nacre surface boxed in $\mathbf{b}$ showing disruption of the aragonite platelets; $\mathbf{e}$ magnification of the nacre surface showing confluence of regular aragonite platelets; f magnification of the nacre platelets showing breaks within the platelets and irregularities of their edges
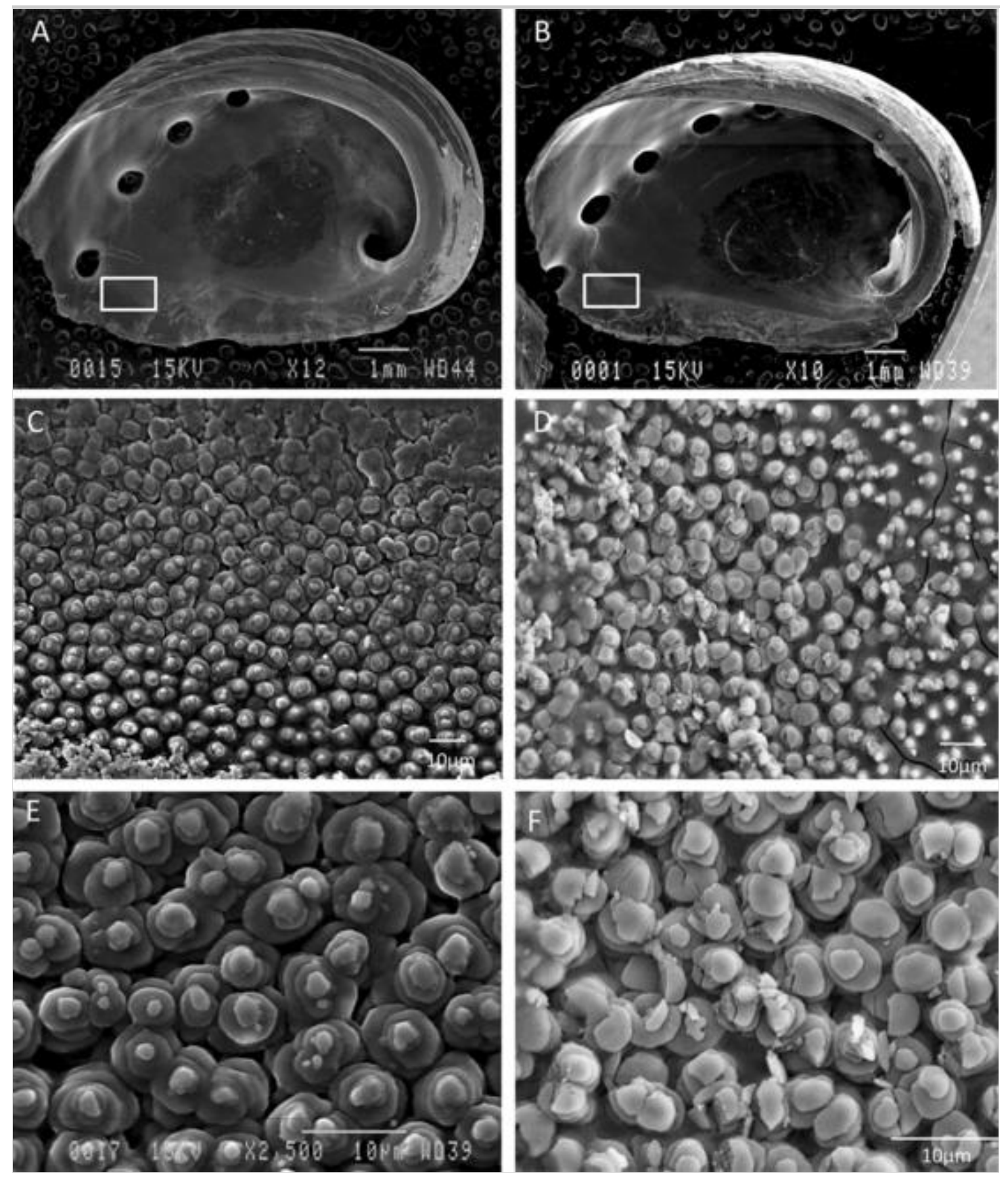

Measurements along the shell section showed a progressive decrease of total shell thickness from older to newly formed shell regions (results not shown), which is in accordance with the shell growth process. Total shell thickness tended to be smaller in juveniles exposed to $\mathrm{pH} 7.6$ compared with those reared under control $\mathrm{pH}_{\mathrm{T}}$ (unpaired $t$ test, $t 8=-2.1644, P=0.062$, Fig. 7a). 
However, a significant reduction of the spherulitic layer thickness was observed at $\mathrm{pH}_{\mathrm{T}} 7.6$ compared with the control group (unpaired $t$ test, $t 8=-$ $2.8522, P=0.021$, Fig. $7 b$ ). There was no significant differences in nacre shell thickness between abalones grown in these two $\mathrm{pH}$ treatments (unpaired $t$ test, $t 8=-0.4381, P=0.67)$.

\section{Fig. 7}

Total thickness (a) and spherulitic layer thickness (b) of juvenile abalone shells grown under control $\mathrm{pH}_{\mathrm{T}}$ (8.1) and low $\mathrm{pH}_{\mathrm{T}}$ (7.6) treatment. Centre lines of box plots show the medians; box limits indicate the first and third quartiles, respectively, with whiskers encompassing data within 1.5 times the spread from the median ( $n=5$ per $\mathrm{pH}$ condition). Asterisk indicates a significant difference between $\mathrm{pH}$ treatments (unpaired Student's $t$ test, $P<0.05$ ) 


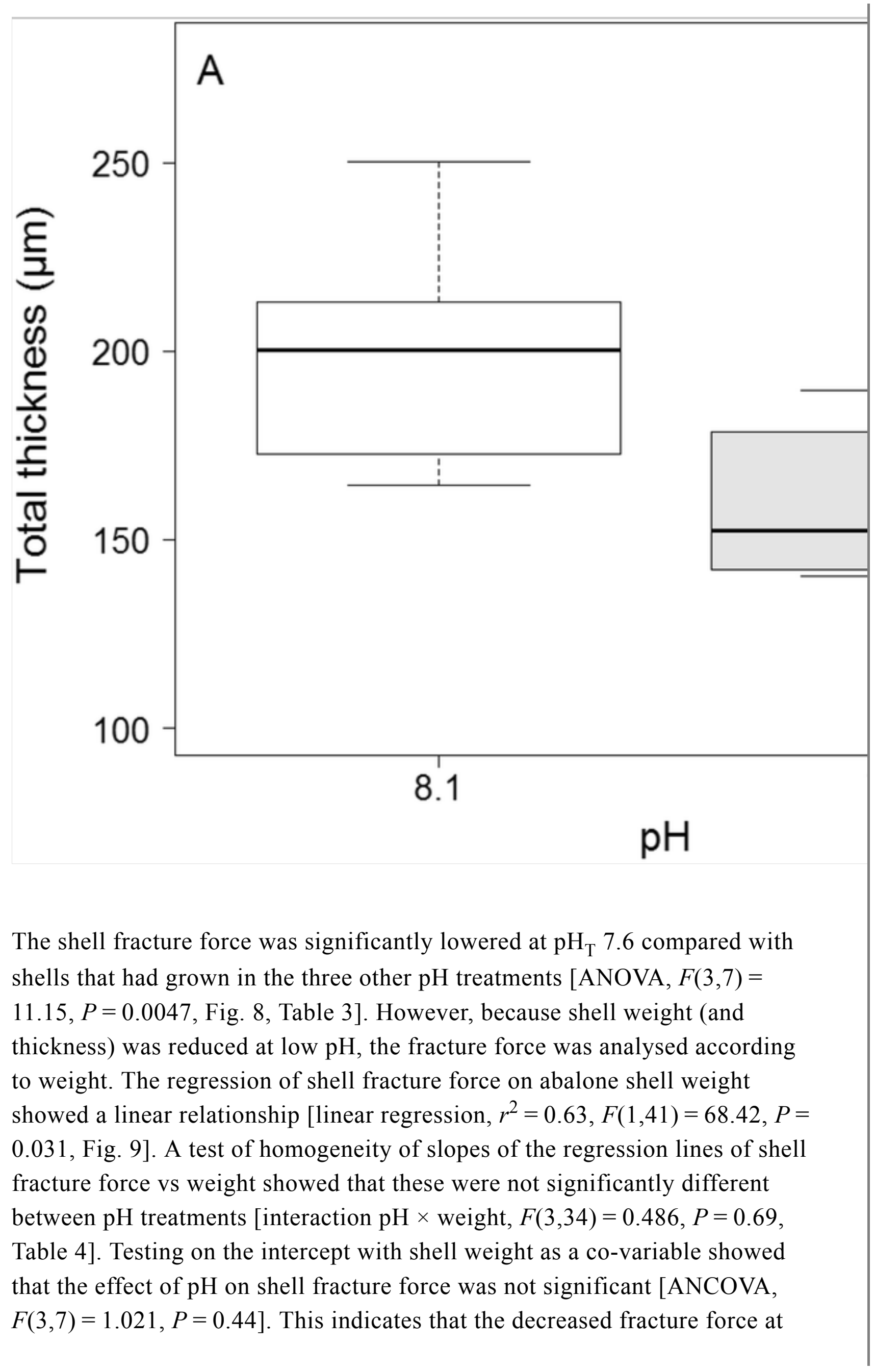


$\mathrm{pH}_{\mathrm{T}} 7.6$ could be explained by the reduced amount of shell material only.

Fig. 8

Fracture force of the shells of abalones reared under different $\mathrm{pH}$ conditions. Centre lines of box plots show the medians; box limits indicate the first and third quartiles, respectively, with whiskers encompassing data within 1.5 times the spread from the median $\left(n=12\right.$ for $\mathrm{pH}_{\mathrm{T}} 8.1$ and $7.8 ; n=11$ for $\mathrm{pH}_{\mathrm{T}} 7.7 ; n=$ 7 for $\mathrm{pH}_{\mathrm{T}}$ 7.6). Different letters indicate significant differences between $\mathrm{pH}$ treatments $(P<0.05)$

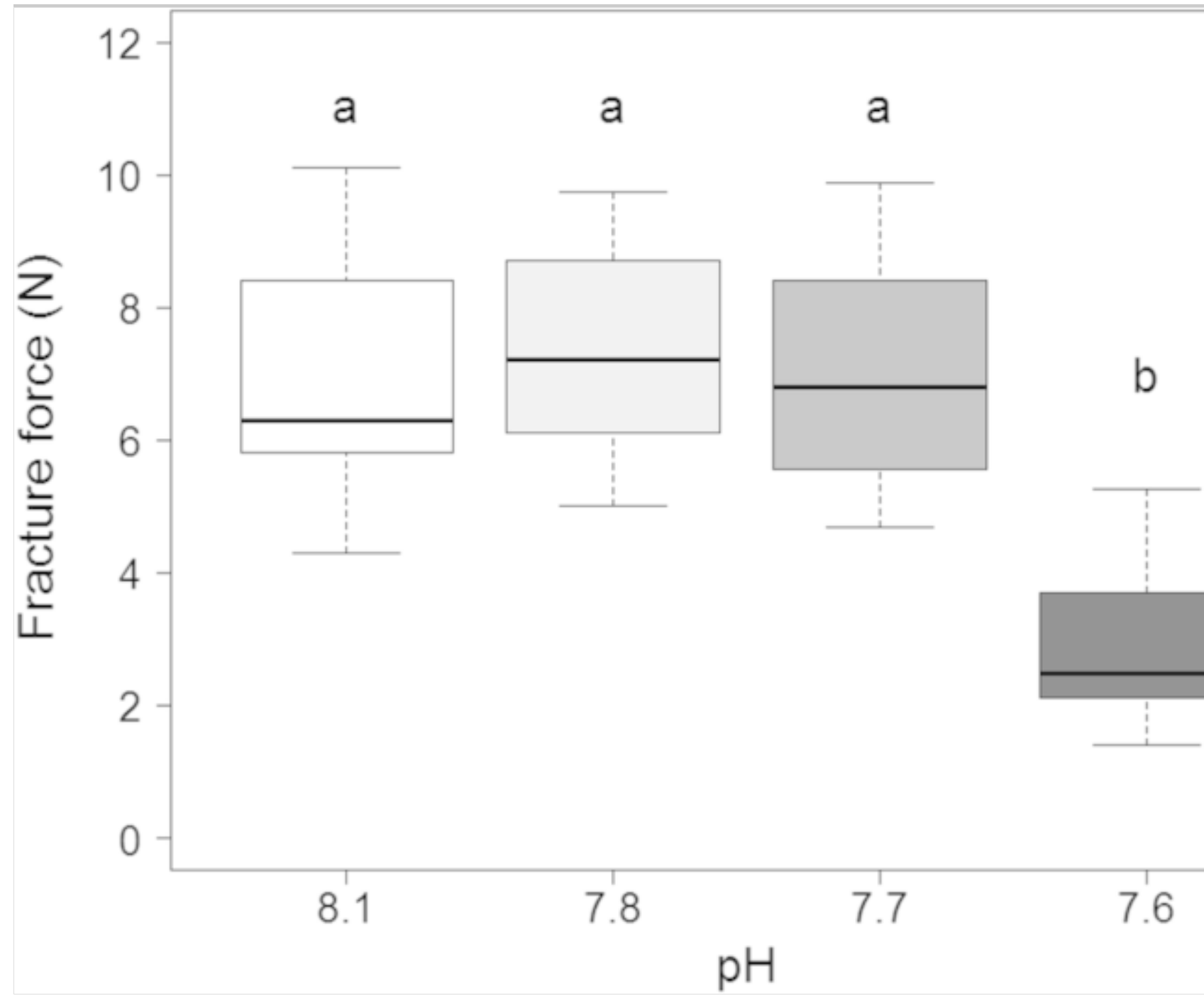

Table 3

Summary of statistics (A) nested ANOVA results of the effects of $\mathrm{pH}$ on shell fracture force in juvenile $H$. tuberculata ( $\mathrm{pH}$ : fixed factor, tank: random factor nested into $\mathrm{pH}$ ), (b) multiple comparison Tukey's HSD test testing the influence of decreased $\mathrm{pH}$ on shell fracture force in juvenile abalone $H$. tuberculata

\begin{tabular}{l|l|l|l} 
SS & MS & $F$ ratio & $P$ value
\end{tabular}


SS

$d f$

MS

$F$ ratio

$P$ value

(A)

\begin{tabular}{|l|l|l|l|l|l|}
\hline $\mathrm{pH}$ & 101.55 & 3 & 33.85 & 11.15 & $\mathbf{0 . 0 0 4 7}$ \\
\hline Residuals & 21.26 & 7 & 3.04 & & \\
\hline Error (tank) & 81.08 & 31 & 2.615 & & \\
\hline pH groups & Estimate & SE & $\boldsymbol{d f}$ & $\boldsymbol{t}$ ratio & $\boldsymbol{P}$ value \\
\hline
\end{tabular}

(B)

\begin{tabular}{|l|l|l|l|l|l|}
\hline $7.6 / 7.7$ & -4.0269558 & 0.8592177 & 7 & -4.687 & $\mathbf{0 . 0 0 9 3}$ \\
\hline $7.6 / 7.8$ & -4.4608812 & 0.8483779 & 7 & -5.258 & $\mathbf{0 . 0 0 5 0}$ \\
\hline $7.6 / 8.1$ & -3.8520031 & 0.8503777 & 7 & -4.530 & $\mathbf{0 . 0 1 1 2}$ \\
\hline $7.7 / 7.8$ & -0.4339255 & 0.7473146 & 7 & -0.581 & 0.9348 \\
\hline $7.7 / 7.8$ & 0.1749527 & 0.7495841 & 7 & 0.233 & 0.9951 \\
\hline $7.8 / 8.1$ & 0.6088781 & 0.7371338 & 7 & 0.826 & 0.8407 \\
\hline
\end{tabular}

Significant $P$ values in bold $(P<0.05)$

Fig. 9

Linear regression of shell fracture force against abalone shell weight $(n=43)$ $\left[r^{2}=0.63, F(1,41)=68.42, P=0.031\right]$ 


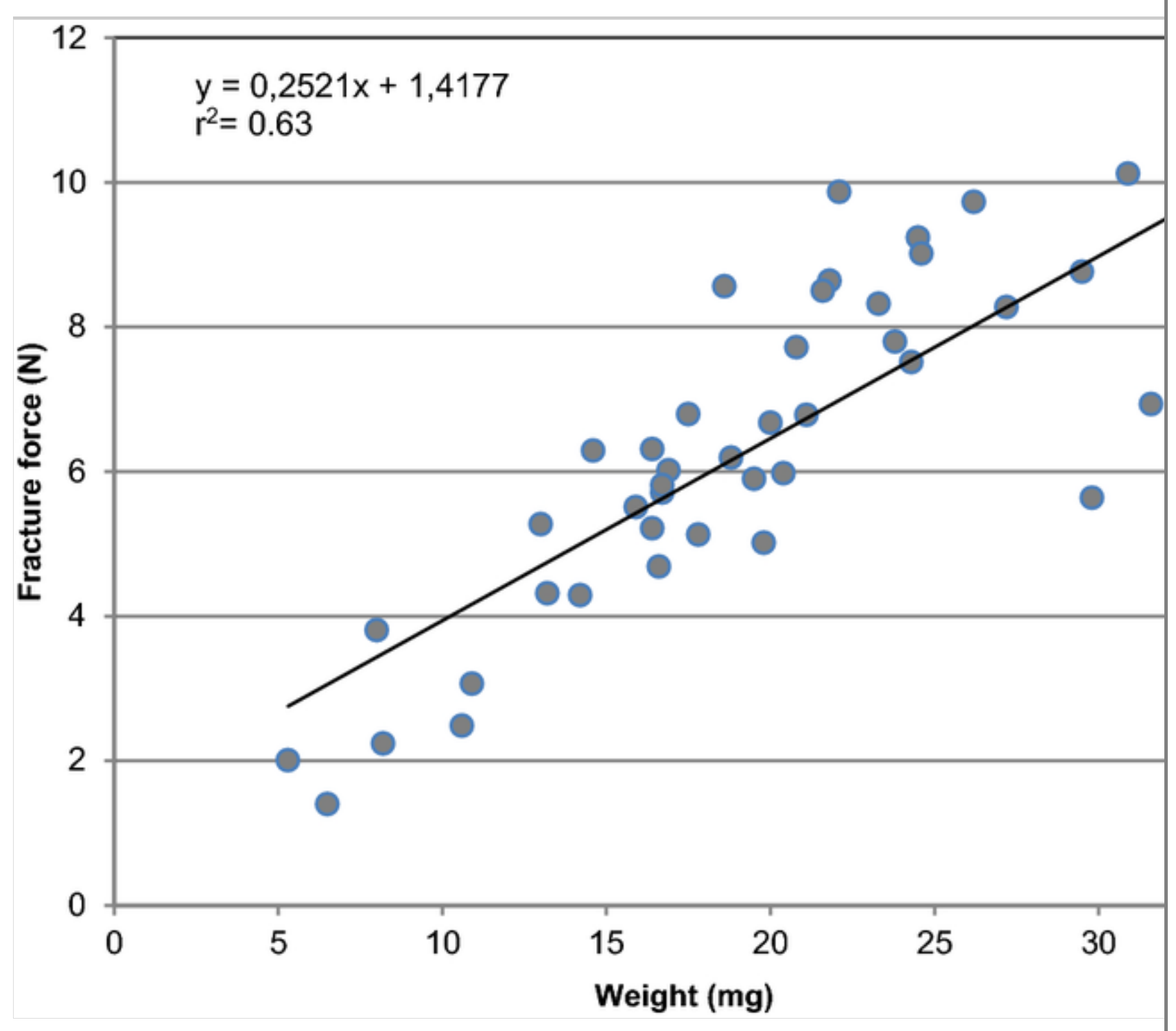

Table 4

Summary of the linear model (ANOVA) testing the effects of decreased $\mathrm{pH}$, weight and the interaction $\mathrm{pH} \times$ weight on the shell fracture force

\begin{tabular}{|l|l|l|l|l|l|}
\hline Source & SS & $\boldsymbol{d f}$ & MS & $\boldsymbol{F}$ ratio & $\boldsymbol{P}$ value \\
\hline $\mathrm{pH}$ & 11.476 & 3 & 3.825 & 2.017 & 0.13 \\
\hline Weight & 125.154 & 1 & 125.154 & 65.967 & $<\mathbf{1 0}^{-\mathbf{8}}$ \\
\hline $\mathrm{pH} \times$ weight & 2.764 & 3 & 0.921 & 0.486 & 0.69 \\
\hline Residuals & 64.496 & 34 & 1.897 & & \\
\hline Significant $P$ values in bold $(P<0.05)$ & & & \\
\hline
\end{tabular}

\section{Discussion}

The present study demonstrated that decreased $\mathrm{pH}$ negatively impacts the 
growth and shell mineralization of juvenile European abalone $H$. tuberculata. Almost all the tested variables were significantly reduced at $\mathrm{pH}_{\mathrm{T}} 7.6(0.5$ units below control $\mathrm{pH}$ ), while $\mathrm{pH}_{\mathrm{T}} 7.7$ and 7.8 did not affect juvenile growth. These results are rather similar to those obtained in two other species of farmed abalone. In juvenile $H$. iris, Cunningham et al. (2016) reported significant effects on shell length and wet weight at $\mathrm{pH}_{\mathrm{NBS}} 7.6$ in winter (corresponding to $\left.\mathrm{pH}_{\mathrm{T}} 7.5\right)$ and at $\mathrm{pH}_{\mathrm{NBS}} 7.8\left(\mathrm{pH}_{\mathrm{T}} 7.7 ; 0.3\right.$ units below control $\mathrm{pH})$ and $7.6\left(\mathrm{pH}_{\mathrm{T}} 7.5 ; 0.5\right.$ units below control $\left.\mathrm{pH}\right)$ in summer. Similarly, shell growth and shell weight were significantly lower in juvenile $H$. discus hannai after 3 months of exposure to $\mathrm{pH}_{\mathrm{NBS}} 7.7$ and 7.9 (corresponding, respectively, to $\mathrm{pH}_{\mathrm{T}} 7.8$ and 7.6, Li et al. 2018). These results are also in accordance with the previous studies on other marine shelled mollusc taxa, showing significant reductions in shell growth following medium-to-long-term exposure to nearfuture $\mathrm{pH}$ (reviewed in Gazeau et al. 2013). In a 2-month experiment, Thomsen and Melzner (2010) observed significant decreases in both shell mass and shell length in blue mussels exposed to lowered $\mathrm{pH}(-0.3$ to -0.9 units). Similarly, the mussel Mytilus galloprovincialis exhibited a slow down of shell growth when $\mathrm{pH}$ was reduced by 0.75 units, possibly caused by dissolution (Michaelidis et al. 2005). As suggested in the previous studies, the effects of OA on shell growth and calcification would result either from a direct effect on $\mathrm{CaCO}_{3}$ dissolution or from indirect metabolic effects, such as physiological and molecular processes regulating shell biomineralization (Beniash et al. 2010; Hüning et al. 2012; Klok et al. 2014). The increasing cost of maintaining acid-base balance combined with an impaired ability to calcify under OA may explain the decrease in the scope for growth among early life stages of molluscs experiencing acidified conditions (Gazeau et al. 2013; Parker et al. 2013; Thomsen et al. 2015). However, Cunningham et al. (2016) found no changes in respiration rate of $H$. iris juveniles subjected to reduced $\mathrm{pH}$ ( -0.3 to -0.5 units), indicating that abalones do not up-regulate their metabolism. Nothing is known on the acid-base balance regulation abilities of abalones but molluscs (apart from cephalopods) are usually considered to have a poor ability to compensate for decreasing haemolymph $\mathrm{pH}$ in situations of seawater acidification (Melzner et al. 2009). According to Cyronak et al. (2016), elevated $\mathrm{H}^{+}$concentration and subsequent problems of homeostasis rather than carbonate ions concentration would be more likely responsible for the reduction of calcification in marine organisms facing OA.

Our results revealed significant changes in shell microstructure of juvenile abalones grown at $\mathrm{pH}_{\mathrm{T}} 7.6$, including corrosion of the outer periostracum and 
degradation of the inner nacreous aragonite layer. In juvenile $H$. discus hannai, corroded periostracum was found in individuals grown at $\mathrm{pH}_{\mathrm{NBS}} 7.7$ (Li et al. 2018), but the effect of decreased $\mathrm{pH}$ on shell microstructure was not investigated. Shell surface corrosion and changes in biomineral microstructure under low $\mathrm{pH}$ have been previously reported in juvenile bivalves and related to a direct effect on shell dissolution (Fitzer et al. 2014b; Hiebenthal et al. 2013; McClintock et al. 2009; Melzner et al. 2011; Waldbusser et al. 2011). It is noteworthy that we only recorded significant effects at $\mathrm{pH}_{\mathrm{T}} 7.6$, the only treatment at which $\Omega$ aragonite was lower than one. The corrosion of the periostracum and degradation of the nacreous layer were observed both in the old part and in the newly formed shell under the low $\mathrm{pH}$, indicating that direct dissolution is involved rather than indirect metabolic process affecting the synthesis of the new shell. However, the energetic cost for proton elimination during $\mathrm{CaCO}_{3}$ precipitation is increased under elevated $p \mathrm{CO}_{2}$, suggesting a metabolic effect.

This finding also supports the hypothesis that the effects on shell length and weight may be mainly due to the shell dissolution. Indeed, the juvenile and adult shells of $H$. tuberculata consist of two biomineralized layers, the outer spherulitic and the inner nacreous layers, both composed of the aragonite $\mathrm{CaCO}_{3}$ polymorph (Auzoux-Bordenave et al. 2010, 2015; Jardillier et al. 2008). The predominance of aragonite in the H. tuberculata shell makes the species more susceptible to dissolution than other mollusc species with calcitic shells or a calcite/aragonite mixture (Gazeau et al. 2013; Parker et al. 2013). In the course of a trans-generational experiment on juvenile M. edulis exposed to elevated $p \mathrm{CO}_{2}$, Fitzer et al. (2014a) revealed that mussels at high $p \mathrm{CO}_{2}(1000 \mu \mathrm{atm})$ did not produce aragonite, which is more vulnerable to carbonate under-saturation than calcite. Under lower $p \mathrm{CO}_{2}(550,750 \mu \mathrm{atm})$, the nacreous tablets formed the usual 'brick wall' structure, although the nacre crystals appeared corroded and were not so closely stacked together as under normal conditions (Fitzer et al. 2014a). This could indicate reduced biological control over biomineralization of aragonite by the organism and potentially raises questions about the integrity of mollusc shells composed only of aragonite under OA.

In addition to changes in shell microstructure, we found a significant reduction in the spherulitic shell thickness and, to a lesser extent, in the total thickness of abalone shells grown at $\mathrm{pH}_{\mathrm{T}}$ 7.6. The reduction of shell thickness is likely due to $\mathrm{CaCO}_{3}$ dissolution of the outer aragonite layer, which would 
be more sensitive to OA after periostracum corrosion. In juvenile shells of $M$. edulis, a reduction in shell thickness was reported in the aragonite layer, but not in the calcite layer, after 6 months of exposure to elevated $p \mathrm{CO}_{2}$ (Fitzer et al. 2014b). Other juvenile bivalves (Argopecten irradians and Mercenaria mercenaria) grown under increased $\mathrm{CO}_{2}$ concentration (corresponding to a reduction of $0.4-0.6 \mathrm{pH}$ units) also exhibited malformed and corroded shells with reduced thickness (Talmage and Gobler 2010). Welladsen et al. (2010) also reported a significant decrease in shell strength and nacre malformation in the adult pearl oyster Pinctada fucata exposed to acidified seawater $\left(\mathrm{pH}_{\mathrm{NBS}}\right.$ 7.6), suggesting shell dissolution.

The integrity of the periostracum (the organic coating of the mollusc shell) is very important for protecting the shell from corrosion induced by low $\mathrm{pH}$ (Thomsen et al. 2010). In juvenile abalone, we found that the periostracum was damaged under low $\mathrm{pH}$, resulting in a higher vulnerability of the underlying mineralized layers. Indeed, a subsequent reduction in thickness of the spherulitic layer as well as changes in the nacreous layer microstructure were observed. These observations are consistent with those reported for other shellfish reared under lowered $\mathrm{pH}$ (Talmage and Gobler 2010). All of this suggests that processes leading to the synthesis of the periostracum are affected by low $\mathrm{pH}$, implying that the kinetics of aragonite precipitation (evidenced by the reduced growth rate) and the thermodynamics of its dissolution (due to under saturated sea water in the $\mathrm{pH}_{\mathrm{T}} 7.6$ treatment) are not the only aspects of the shell being affected. Potential effects of decreased $\mathrm{pH}$ on shell organic components (chitin and matrix proteins) may explain the corrosion of the periostracum and some of the changes observed in the nacre microstructure, but the underlying mechanisms are far from being understood (Fitzer et al. 2014b; Hüning et al. 2012). A number of indirect biological processes involved in shell calcification, such as matrix protein production, chitin synthesis, and enzymatic control, are influenced by changes in seawater $p \mathrm{CO}_{2}$ (Weiss et al. 2013). In the mussel M. edulis, 6 months of incubation at $750 \mu$ atm $p \mathrm{CO}_{2}\left(\mathrm{pH}_{\mathrm{T}} 7.5\right)$ significantly reduced carbonic anhydrase activity within the mantle tissue, explaining shell growth reduction (Fitzer et al. 2014b). In another study of $M$. edulis, a strong depression in the expression of mRNA for a chitinase, an enzyme involved in the calcification process, was correlated with a linear decrease in shell growth (Hüning et al. 2012). Interestingly, this study also found that expression of several genes, including some genes involved in shell protection and/or periostracum formation (tyrosinase) increased in response to elevated $p \mathrm{CO}_{2}$ (Hüning et al. 2012). By 
contrast, despite evidence of shell dissolution, no difference was found in the organic content or periostracum integrity of adult $P$. fucata shells exposed to $\mathrm{pH}_{\mathrm{NBS}} 7.6$ (Welladsen et al. 2010). However, the authors noted that because the study was conducted over only a 28 -day period, it did not allow acclimation of the oysters to the acidified conditions.

In juvenile $H$. tuberculata, the significant reduction in shell fracture force at $\mathrm{pH}_{\mathrm{T}} 7.6$ can be explained by the reduced shell weight. This probably results from both reduced growth and shell dissolution. A smaller (isometric) dome is submitted to a higher meridional compressive stress for the same external force applied and will, therefore, rupture at a lower applied force (Vogel 2003). Shell dissolution will induce an easier induction of cracks and cleavage, probably initiated by dissolution pits inducing stress concentration at their level (McNeill 1968). Both effects would increase the period during which abalone are exposed to strong predation pressure before they reach a refuge in size and shell strength. This would have an economic impact on abalone aquaculture as it would increase the time required to reach a marketable size and possibly enhance productivity losses through shell breakage during handling.

Marine molluscs exert a strong control on the calcification process, but their capacities to maintain optimal conditions at the site of calcification when facing OA stress remain largely unknown (Gazeau et al. 2013; Parker et al. 2013). Because shell calcification has a high energetic cost and is very sensitive to OA (especially in early stages), energy usually allocated to growth and reproduction might be partially reallocated to calcification (Thomsen and Melzner 2010). The capacity of abalone to grow in the near future will depend on their potential to maintain their vital functions (reproduction, growth, and biomineralization) under modified environmental conditions. Since responses to OA may also differ according to differences in physiology, habitat, and behaviour of the species (Gazeau et al. 2013), the local seasonal variations in physico-chemical conditions should be considered in further studies on adaptive responses. The seawater $\mathrm{pH}_{\mathrm{T}}$ along the Brittany coast in France naturally varies from 7.9 to 8.2 (Qui-Minet et al. 2018), so that a future scenario testing a decrease of -0.3 units from ambient $\mathrm{pH}_{\mathrm{T}}$ is consistent with seasonal or diurnal variations presently experienced by abalone in the tidal zone. Indeed, seasonal variations in $\mathrm{pH}$ are close to 0.3 units in shallow subtidal environments (Qui-Minet et al. 2018), while diurnal variations of $\mathrm{pH}_{\mathrm{T}}$ in the intertidal zone can be higher. For instance, $\mathrm{pH}$ can fall 
down to $\mathrm{pH}_{\mathrm{T}} 7.5$ in rock pools along the Brittany coast during night-time emersion at low tide (Legrand et al. 2018). Thus, abalone from Brittany shoreline environments might already experience chronically $\mathrm{pH}$ similar to global average $\mathrm{pH}$ levels predicted for open ocean by 2100 (i.e., $\mathrm{pH}_{\mathrm{T}}$ 7.7). Such fluctuations of $\mathrm{pH}$ in their coastal habitats might explain the potential resistance of abalone to $\mathrm{pH}_{\mathrm{T}}>7.6$.

The results of our study indicate that a decrease of $0.5 \mathrm{pH}$ units significantly reduces growth, shell calcification and shell strength of juvenile abalone $H$. tuberculata. In the natural environment, where juvenile stages are exposed to a strong predation pressure, abalone may be at greater risk under future $\mathrm{pH}$ conditions as their shells may not offer sufficient protection from predators and other external stressors. Understanding how different abalone life stages respond to OA will make it possible to identify bottlenecks for population persistence under near-future $\mathrm{pH}$ conditions. These findings also highlight the importance of monitoring seawater parameters in aquaculture systems, where effort can be directed to maintaining seawater $\mathrm{pH}$ at key periods of abalone culture to minimize stress and prevent production losses.

AQ2

\section{Publisher's Note}

Springer Nature remains neutral with regard to jurisdictional claims in published maps and institutional affiliations.

\section{Acknowledgements}

N. Wessel was supported by a postdoctoral fellowship from the MNHN (Ministère de l'Enseignement Supérieur et de la Recherche, Paris, France). This work was supported in part by the ATM program "Biomineralization" of the MNHN funded by the Ministère délégué à l'Enseignement Supérieur et à la Recherche (Paris, France) and by the ICOBio project under the program "Acidification des Océans" funded by the Fondation pour la Recherche sur la Biodiversité (FRB) and the Ministère de la Transition Ecologique et Solidaire (MTES). We thank Dr. Chakib Djejat and Stéphane Formosa for their assistance in scanning electron microscopy (SEM, Plateau technique de Microscopie Electronique, MNHN, Paris and Concarneau, France). The Regional Council of Brittany, the General Council of Finistère, the urban community of Concarneau Cornouaille Agglomération and the European Regional Development Fund (ERDF) are acknowledged for the funding of the Sigma 300 FE-SEM of the Concarneau Marine Station. We thank Dr. Cedric 
Hubas for his valuable support for the statistical analyses and the Translation Bureau of the University of Western Brittany for improving the English of this manuscript. We also thank the three anonymous reviewers for their comments which have helped to improve this manuscript. Ph. Dubois is a Research Director of the National Fund for Scientific Research (Belgium).

Compliance with ethical standards

Conflict of interest The authors declare that they have no conflicts of interest or competing financial interests.

Ethical approval The experiments complied with the current French laws. All applicable international, national, and institutional guidelines for the care and use of animals were followed.

\section{Electronic supplementary material}

Below is the link to the electronic supplementary material.

Supplementary material 1 (PDF 157 kb) Supplementary material 2 (PDF 82 kb)

\section{References}

Auzoux-Bordenave S, Badou A, Gaume B, Berland S, Helléouet M-N, Milet C, Huchette S (2010) Ultrastructure, chemistry and mineralogy of the growing shell of the European abalone Haliotis tuberculata. J Struct Biol 171:277-290. https://doi.org/10.1016/j.jsb.2010.05.012

Auzoux-Bordenave S, Brahmi C, Badou A, De Rafélis M, Huchette S (2015) Shell growth, microstructure and composition over the development cycle of the European abalone Haliotis tuberculata. Mar Biol 162:687-697. https://doi.org/10.1007/s00227-015-2615-y

Beniash E, Ivanina A, Lieb NS, Kurochkin I, Sokolova IM (2010) Elevated level of carbon dioxide affects metabolism and shell formation in oysters Crassostrea virginica. Mar Ecol Prog Ser 419:95-108. https://doi.org $/ 10.3354 /$ meps 08841

Byrne M, Ho M, Wong E, Soars NA, Selvakumaraswamy P, ShepardBrennand H, Dworjanyn SA, Davis AR (2011) Unshelled abalone and 
corrupted urchins: development of marine calcifiers in a changing ocean. Proc R Soc B Biol Sci 278:2376-2383. https://doi.org/10.1098 /rspb.2010.2404

Cook PA (2014) The worldwide abalone industry. Mod Econ 05:1181-1186. https://doi.org/10.4236/me.2014.513110

Courtoisde Viçose G, Viera MP, Bilbao A, Izquierdo MS (2007) Embryonic and larval development of Haliotis tuberculata coccinea Reeve: an indexed micro-photographic sequence. J Shellfish Res 26:847-854. https://doi.org/10.2983 /0730-8000(2007)26\%5b847:EALDOH\%5d2.0.CO;2

Crim RN, Sunday JM, Harley CDG (2011) Elevated seawater $\mathrm{CO}_{2}$ concentrations impair larval development and reduce larval survival in endangered northern abalone (Haliotis kamtschatkana). J Exp Mar Biol Ecol 400:272-277. https://doi.org/10.1016/j.jembe.2011.02.002

Cunningham SC, Smith AM, Lamare MD (2016) The effects of elevated $p \mathrm{CO}_{2}$ on growth, shell production and metabolism of cultured juvenile abalone, Haliotis iris. Aquac Res 47:2375-2392. https://doi.org/10.1111 /are. 12684

Cyronak T, Schulz KG, Jokiel PL (2016) The Omega myth: what really drives lower calcification rates in an acidifying ocean. ICES J Mar Sci 73:558-562. https://doi.org/10.1093/icesjms/fsv075

Day RW, Quinn GP (1989) Comparisons of treatments after an analysis of variance in ecology. Ecol Monogr 59:433-463. https://doi.org/10.2307 $/ 1943075$

Dickson AG (2010) Standards for ocean measurements. Oceanography 23:34-47. https://doi.org/10.5670/oceanog.2010.22

Dickson AG, Millero FJ (1987) A comparison of the equilibrium constants for the dissociation of carbonic acid in seawater media. Deep Sea Res 34:1733-1743

Dickson AG, Sabine CL, Christian JR (2007) Guide to best practices for ocean $\mathrm{CO}_{2}$ measurements. PICES Special Publications 3 
Doney SC, Fabry VJ, Feely RA, Kleypas JA (2009) Ocean acidification: the other $\mathrm{CO}_{2}$ problem. Annu Rev Mar Sci 1:169-192. https://doi.org /10.1146/annurev.marine.010908.163834

Duquette A, McClintock JB, Amsler CD, Pérez-Huerta A, Milazzo M, Hall-Spencer JM (2017) Effects of ocean acidification on the shells of four Mediterranean gastropod species near a $\mathrm{CO}_{2}$ seep. Mar Pollut Bull 124:917-928. https://doi.org/10.1016/j.marpolbul.2017.08.007

Ekstrom JA, Suatoni L, Cooley SR, Pendleton LH, Waldbusser GG, Cinner JE, Ritter J, Langdon C, Van Hooidonk R, Gledhill D, Wellman K, Beck MW, Brander LM, Rittschof D, Doherty C, Edwards PET, Portela R (2015) Vulnerability and adaptation of US shellfisheries to ocean acidification. Nat Clim Change 5:207-214. https://doi.org/10.1038/nclimate2508

Ellis RP, Bersey J, Rundle SD, Hall-Spencer JM, Spicer JI (2009) Subtle but significant effects of $\mathrm{CO}_{2}$ acidified seawater on embryos of the intertidal snail, Littorina obtusata. Aquat Biol 5:41-48. https://doi.org $/ 10.3354 / \mathrm{ab} 00118$

Fitzer SC, Cusack M, Phoenix VR, Kamenos NA (2014a) Ocean acidification reduces the crystallographic control in juvenile mussel shells. J Struct Biol 188:39-45. https://doi.org/10.1016/j.jsb.2014.08.007

Fitzer SC, Phoenix VR, Cusack M, Kamenos NA (2014b) Ocean acidification impacts mussel control on biomineralisation. Sci Rep 4:6218. https://doi.org/10.1038/srep06218

Gallardo WG, Bautista-Teruel MN, Fermin AC, Marte CL (2003) Shell marking by artificial feeding of the tropical abalone Haliotis asinina Linne juveniles for sea ranching and stock enhancement. Aquac Res 34:839-842

Gattuso JP, Magnan A, Bille R, Cheung WWL, Howes EL, Joos F, Allemand D, Bopp L, Cooley SR, Eakin CM, Hoegh-Guldberg O, Kelly RP, Portner HO, Rogers AD, Baxter JM, Laffoley D, Osborn D, Rankovic A, Rochette J, Sumaila UR, Treyer S, Turley C (2015) Contrasting futures for ocean and society from different anthropogenic $\mathrm{CO}_{2}$ emissions scenarios. Science 349:4722. https://doi.org/10.1126/science.aac4722 
Gazeau F, Quiblier C, Jansen JM, Gattuso J-P, Middelburg JJ, Heip CHR (2007) Impact of elevated $\mathrm{CO}_{2}$ on shellfish calcification. Geophys Res Lett. https://doi.org/10.1029/2006g1028554

Gazeau F, Gattuso JP, Dawber C, Pronker AE, Peene F, Peene J, Heip CHR, Middelburg JJ (2010) Effect of ocean acidification on the early life stages of the blue mussel Mytilus edulis. Biogeosciences 7:2051-2060. https://doi.org/10.5194/bg-7-2051-2010

Gazeau F, Parker LM, Comeau S, Gattuso J-P, O’Connor WA, Martin S, Pörtner H-O, Ross PM (2013) Impacts of ocean acidification on marine shelled molluscs. Mar Biol 160:2207-2245. https://doi.org/10.1007 /s00227-013-2219-3

Guo X, Huang M, Pu F, You W, Ke C (2015) Effects of ocean acidification caused by rising $\mathrm{CO}_{2}$ on the early development of three mollusks. Aquat Biol 23:147-157. https://doi.org/10.3354/ab00615

Hendriks IE, Duarte CM, Álvarez M (2010) Vulnerability of marine biodiversity to ocean acidification: a meta-analysis. Estuar Coast Shelf Sci 86:157-164. https://doi.org/10.1016/j.ecss.2009.11.022

Hiebenthal C, Philipp EER, Eisenhauer A, Wahl M (2013) Effects of seawater $p \mathrm{CO}_{2}$ and temperature on shell growth, shell stability, condition and cellular stress of Western Baltic Sea Mytilus edulis (L.) and Arctica islandica (L.). Mar Biol 160:2073-2087. https://doi.org/10.1007 /s00227-012-2080-9

Hofmann GE, Barry JP, Edmunds PJ, Gates RD, Hutchins DA, Klinger T, Sewell MA (2010) The effect of ocean acidification on calcifying organisms in marine ecosystems: an organism to-ecosystem perspectiv. Annu Rev Ecol Evol Syst 41:127-147. https://doi.org/10.1146 /annurev.ecolsys.110308.120227

Huchette S, Clavier J (2004) Status of the ormer (Haliotis tuberculata L.) industry in Europe. J Shellfish Res 23:951-955

Hüning AK, Melzner F, Thomsen J, Gutowska MA, Krämer L, Frickenhaus S, Rosenstiel P, Pörtner H-O, Philipp EER, Lucassen M (2012) Impacts of seawater acidification on mantle gene expression patterns of the Baltic Sea 
blue mussel: implications for shell formation and energy metabolism. Mar Biol 160:1845-1861. https://doi.org/10.1007/s00227-012-1930-9

IPCC (2014) Summary for policymakers. In: Climate change 2014: impacts, adaptation, and vulnerability. Part A: global and sectoral aspects. Contribution of working group II to the fifth assessment report of the intergovernmental panel on climate change. Cambridge University Press, Cambridge, pp 1-32

Jardillier E, Rousseau M, Gendron-Badou A, Fröhlich F, Smith DC, Martin M, Helléouet M-N, Huchette S, Doumenc D, Auzoux-Bordenave S (2008) A morphological and structural study of the larval shell from the abalone Haliotis tuberculata. Mar Biol 154(4):735-744

Kimura RYO, Takami H, Ono T, Onitsuka T, Nojiri Y (2011) Effects of elevated $p \mathrm{CO}_{2}$ on the early development of the commercially important gastropod, Ezo abalone Haliotis discus hannai. Fish Oceanogr 20:357-366. https://doi.org/10.1111/j.1365-2419.2011.00589.x

Klok C, Wijsman JWM, Kaag K, Foekema E (2014) Effects of $\mathrm{CO}_{2}$ enrichment on cockle shell growth interpreted with a dynamic energy budget model. J Sea Res 94:111-116

Kroeker KJ, Kordas RL, Crim RN, Singh GG (2010) Meta-analysis reveals negative yet variable effects of ocean acidification on marine organisms. Ecol Lett 13:1419-1434. https://doi.org/10.1111/j.1461-0248.2010.01518.x

Kurihara $\mathrm{H}$ (2008) Effects of $\mathrm{CO}_{2}$-driven ocean acidification on the early developmental stages of invertebrates. Mar Ecol Prog Ser 373:275-284. https://doi.org/10.3354/meps07802

Legrand E, Riera P, Pouliquen L, Bohner O, Cariou T, Martin S (2018) Ecological characterization of intertidal rockpools: seasonal and diurnal monitoring of physico-chemical parameters. Reg Stud Mar Sci 17:1-10. https://doi.org/10.1016/j.rsma.2017.11.003

Li J, Mao Y, Jiang Z, Zhang J, Fang J, Bian D (2018) The detrimental effects of $\mathrm{CO}_{2}$-driven chronic acidification on juvenile Pacific abalone (Haliotis discus hannai). Hydrobiologia 809:297-308. https://doi.org /10.1007/s10750-017-3481-z 
Marchais V, Jolivet A, Herve S, Roussel S, Schone BR, Grall J, Chauvaud L, Clavier J (2017) New tool to elucidate the diet of the ormer Haliotis tuberculata (L.): digital shell color analysis. Mar Biol 164(4):1-13

Martin S, Richier S, Pedrotti ML, Dupont S, Castejon C, Gerakis Y, Kerros ME, Oberhansli F, Teyssie JL, Jeffree R, Gattuso JP (2011) Early development and molecular plasticity in the Mediterranean sea urchin Paracentrotus lividus exposed to $\mathrm{CO}_{2}$-driven acidification. J Exp Biol 214:1357-1368. https://doi.org/10.1242/jeb.051169

McClintock JB, Angus RA, Mcdonald MR, Amsler CD, Catledge SA, Vohra YK (2009) Rapid dissolution of shells of weakly calcified Antarctic benthic macroorganisms indicates high vulnerability to ocean acidification. Antarct Sci 21:449-456. https://doi.org/10.1017/S0954102009990198

McNeill AR (1968) Animal mechanics. Sidgwick and Jackson, London

Mehrbach C, Culberson CH, Hawley JE, Pytkowicx RM (1973)

Measurement of the apparent dissociation constants of carbonic acid in seawater at atmospheric pressure. Limnol Oceanogr 18:897-907. https://doi.org/10.4319/1o.1973.18.6.0897

Melzner F, Gutowska MA, Langenbuch M, Dupont S, Lucassen M, Thorndyke MC, Bleich M, Portner HO (2009) Physiological basis for high $\mathrm{CO}_{2}$ tolerance in marine ectothermic animals: pre-adaptation through lifestyle and ontogeny? Biogeosciences 6:2313-2331

Melzner F, Stange P, Trübenbach K, Thomsen J, Casties I, Panknin U, Gorb SN, Gutowska MA (2011) Food supply and seawater $p \mathrm{CO}_{2}$ impact calcification and internal shell dissolution in the blue mussel Mytilus edulis. PLoS One. https://doi.org/10.1371/journal.pone.0024223

Mercer JP, Mai KS, Donlon J (1993) Comparative studies on the nutrition of 2 species of abalone, Haliotis tuberculata Linnaeus and Haliotis discus hannai Ino. 1. Effects of algal diets on growth and biochemical composition. Invertebr Reprod Dev 23:75-88

Michaelidis B, Ouzounis C, Paleras A, Pörtner H-O (2005) Effects of longterm moderate hypercapnia on acid-base balance and growth rate in marine mussels Mytilus galloprovincialis. Mar Ecol Prog Ser 293:109-118 
Morash AJ, Alter K (2015) Effects of environmental and farm stress on abalone physiology: perspectives for abalone aquaculture in the face of global climate change. Rev Aquac 7:1-27. https://doi.org/10.1111 /raq.12097

Morse JW, Arvidson RS, Luttge A (2007) Calcium carbonate formation and dissolution. Chem Rev 107:342-381. https://doi.org/10.1021 /cr050358j

Nicolas JL, Basuyaux O, Mazurié J, Thébault A (2002) Vibrio carchariae, a pathogen of the abalone Haliotis tuberculata. Dis Aquat Organ 50:35-43

Noisette F, Comtet T, Legrand E, Bordeyne F, Davoult D, Martin S (2014) Does encapsulation protect embryos from the effects of ocean acidification? The example of Crepidula fornicata. PLoS One. https://doi.org/10.1371/journal.pone.0093021

Onitsuka T, Takami H, Muraoka D, Matsumoto Y, Nakatsubo A, Kimura R, Ono T, Nojiri Y (2018) Effects of ocean acidification with $p \mathrm{CO}_{2}$ diurnal fluctuations on survival and larval shell formation of Ezo abalone, Haliotis discus hannai. Mar Environ Res 134:28-36. https://doi.org/10.1016 /j.marenvres.2017.12.0152

Orr JC, Fabry VJ, Aumont O, Bopp L, Doney SC, Feely RA, Gnanadesikan A, Gruber N, Ishida A, Joos F, Key RM, Lindsay K, Maier-Reimer E, Matear R, Monfray P, Mouchet A, Najjar RG, Plattner G-K, Rodgers KB, Sabine CL, Sarmiento JL, Schlitzer R, Slater RD, Totterdell IJ, Weirig M-F, Yamanaka Y, Yool A (2005) Anthropogenic ocean acidification over the twenty-first century and its impact on calcifying organisms. Nature 437:681-686. https://doi.org/10.1038/nature04095

Parker L, Ross P, O’Connor W, Pörtner H, Scanes E, Wright J (2013) Predicting the response of molluscs to the impact of ocean acidification. Biology 2:651-692. https://doi.org/10.3390/biology2020651

Pierrot DE, Lewis E, Wallace DWR (2006) MS Excel program developed for $\mathrm{CO}_{2}$ system calculations. ORNL/CDIAC-105a. Carbon Dioxide Information Analysis Center. Oak Ridge National Laboratory, US Department of Energy, Oak Ridge, Tennessee 
Przeslawski R, Byrne M, Mellin C (2015) A review and meta-analysis of the effects of multiple abiotic stressors on marine embryos and larvae. Glob Change Biol 21:2122-2140. https://doi.org/10.1111/gcb.12833

Qui-Minet ZN, Delaunay C, Grall J, Six C, Cariou T, Bohner O, Legrand E, Davoult D, Martin S (2018) The role of local environmental changes on maerl and its associated non-calcareous epiphytic flora in the Bay of Brest. Estuar Coast Shelf Sci 208:140-152. https://doi.org/10.1016 /j.ecss.2018.04.032

Riebesell U, Fabry VJ, Hansson L, Gattuso JP (2010) Guide to best practices for ocean acidification research and data reporting. Publications Office of the European Union

Ross PM, Parker L, O'Connor WA, Bailey EA (2011) The impact of ocean acidification on reproduction, early development and settlement of marine organisms. Water 3:1005-1030. https://doi.org/10.3390/w3041005

Shepherd SA (1973) Studies on southern Australian abalone (genus Haliotis). I. Ecology of five sympatric species. Aust J Mar Freshw Res $24: 217-257$

Talmage SC, Gobler CJ (2010) Effects of past, present, and future ocean carbon dioxide concentrations on the growth and survival of larval shellfish. PNAS 107:17246-17251. https://doi.org/10.1073 /pnas.0913804107

R Core Team (2015) R Core Team: a language and environment for statistical computing. Vienna, Austria

Thomsen J, Melzner F (2010) Moderate seawater acidification does not elicit long-term metabolic depression in the blue mussel Mytilus edulis. Mar Biol 157:2667-2676. https://doi.org/10.1007/s00227-010-1527-0

Thomsen J, Gutowska MA, Saphörster J, Heinemann A, Trübenbach K, Fietzke K, Hiebenthal C, Eisenhauer A, Körtzinger A, Wahl M, Melzner F (2010) Calcifying invertebrates succeed in a naturally $\mathrm{CO}_{2}$-rich coastal habitat but are threatened by high levels of future acidification. Biogeosciences 7:3879-3891. https://doi.org/10.5194/bg-7-3879-2010 
Thomsen J, Haynert K, Wegner KM, Melzner F (2015) Impact of seawater carbonate chemistry on the calcification of marine bivalves.

Biogeosciences 12:4209-4220. https://doi.org/10.5194/bg-12-4209-2015

Travers M-A, Basuyaux O, Le Goic N, Huchette S, Nicolas J-L, Koken M, Paillard C (2009) Influence of temperature and spawning effort on Haliotis tuberculata mortalities caused by Vibrio harveyi: an example of emerging vibriosis linked to global warming. Glob Change Biol 15:1365-1376. https://doi.org/10.1111/j.1365-2486.2008.01764.x

Vogel S (2003) Comparative biomechanics. Princeton University Press, Princeton

Waldbusser GG, Steenson RA, Green MA (2011) Oyster shell dissolution rates in estuarine waters: effects of $\mathrm{pH}$ and shell legacy. J Shellfish Res 30:659-670

Weiss IM, Lüke F, Eichner N, Guth C, Clausen-Schaumann H (2013) On the function of chitin synthase extracellular domains in biomineralization. J Struct Biol 183:216-225. https://doi.org/10.1016/j.jsb.2013.04.011

Welladsen HM, Southgate PC, Heimann K (2010) The effects of exposure to near-future levels of ocean acidification on shell characteristics of Pinctada fucata (Bivalvia: Pteriidae). Molluscan Res 30:125-130

Wessel N, Martin S, Badou A, Dubois P, Huchette S, Julia V, Nunes F, Harney E, Paillard C, Auzoux-Bordenave S (2018) Effect of $\mathrm{CO}_{2}$-induced ocean acidification on the early development and shell mineralization of the European abalone Haliotis tuberculata. J Exp Mar Biol Ecol 508:52-63

Widdicombe S, Spicer JI (2008) Predicting the impact of ocean acidification on benthic biodiversity: what can animal physiology tell us? J Exp Mar Biol Ecol 366:187-197. https://doi.org/10.1016 /j.jembe.2008.07.024

Wittmann AC, Pörtner H-O (2013) Sensitivities of extant animal taxa to ocean acidification. Nat Clim Change 3:995-1001. https://doi.org/10.1038 /NCLIMATE1982

Zippay ML, Hofmann GE (2010) Effect of pH on gene expression and 
thermal tolerance of early life history stages of red abalone (Haliotis rufescens). J Shellfish Res 29:429-439 